\title{
Antecedents and Outcomes of Strategic IS Alignment: An Empirical Investigation
}

\author{
Yolande E. Chan, Rajiv Sabherwal, and Jason Bennett Thatcher
}

\begin{abstract}
Prior research argues that alignment between business and information systems (IS) strategies enhances organizational performance. However, factors affecting alignment have received relatively little empirical attention. Moreover, IS strategic alignment is assumed to facilitate the performance of all organizations, regardless of type or business strategy. By using two studies of business firms and academic institutions, this paper: 1) develops and tests a model relating alignment, its antecedents, and its consequences and 2) examines differences in these relationships across organizational types and strategies. Findings indicate that alignment depends on shared domain knowledge and prior IS success, and also support the expected positive impact of alignment on organizational performance. Differences across Prospector, Analyzer, and Defender business strategies are examined. A key research contribution is the empirical demonstration that the importance of alignment, as well as the mechanisms used to attain alignment, vary by business strategy and industry. In past alignment studies, controlling for industry has not been uncommon. The findings suggest that future research studies should also control for business strategy. The article also empirically demonstrates that past implementation success influences alignment. In addition, it highlights the influence of a process variable, strategic planning, on the development of shared knowledge and, consequently, on alignment.

This paper examines strategic issues related to the management of technology. Data from multiple surveys are used to test the extent to which strategic planning, shared business-IS knowledge, prior IS success, and other variables consistently enhance IS alignment. The study also provides empirical support for the popular argument that IS alignment improves organizational performance. It extends the current literature by examining the extent to which these findings hold across firm strategies and industries. The authors argue that not all firms are equally well served by allocating scarce resources to improve IS alignment.
\end{abstract}

Index Terms-Academic institutions, antecedents of alignment, business strategy, information systems strategy, organizational characteristics, organizational performance, strategic alignment.

\section{INTRODUCTION}

$\mathbf{T}$ HE IMPORTANCE of aligning the information systems (IS) function with other business functions is widely recognized (e.g., [8], [54], and [58]). Empirical studies have found IS strategic alignment-which is defined as the degree to which the mission, objectives and plans contained in the business strategy are shared and supported by the IS strategy [54]—-to influence business performance [31], [56]. Alignment involves

Manuscript received August 1, 2004; revised January 1, 2005 and July 1, 2005. Review of this manuscript was arranged by Department Editor A. S. Bean. Y. E. Chan is with the Queen's School of Business, Queen's University, Kingston, ON K7L 3N6, Canada (e-mail: ychan@ business.queensu.ca).

R. Sabherwal is with the University of Missouri, St. Louis, MO 63121 USA.

J. B. Thatcher is with the Department of Management, College of Business and Behavioral Science, Clemson University, Clemson, SC 29631 USA.

Digital Object Identifier 10.1109/TEM.2005.861804 "applying information technology (IT) in an appropriate and timely way and in harmony with business strategies, goals, and needs" [42, p. 109].

Few today would question the importance of strategic IS alignment (hereafter called alignment) [11], [16], [20], [31]. However, as noted by several authors (e.g., [9], [43], and [55]), there has been little theory-based empirical research on the relative importance of the factors affecting it. Therefore, the first specific objective of this paper is to provide additional empirical insight into the factors affecting alignment. To pursue this objective, a theoretical model of the performance impacts of alignment and its antecedent factors is developed and empirically tested. The second objective of this paper is to provide insights into the differences between business firms and academic institutions, and across business strategies, in the impacts of alignment and the factors affecting it. This is important due to a common implicit assumption that alignment is universally important, across all organizations and business strategies, although a recent study [56] questions this assumption.

By pursuing these objectives, this paper makes important contributions to research and practice. First, it provides additional empirical analyses that are needed to demonstrate the relative importance of various factors and processes in achieving alignment. It presents a comprehensive quantitative assessment of major antecedents of alignment. Second, it explores empirically whether all firms benefit equally from IS alignment. The study demonstrates that the type of firm (public or private), industry, and firm strategy all influence the extent to which alignment matters.

The paper draws upon a substantial body of prior research to develop the theoretical model, as elaborated upon later. Empirically, the paper is based on data from two survey-based studies of business firms [56] and academic institutions [57]. However, it differs significantly from both those papers. One important difference from these prior studies relates to our second research objective: unlike Sabherwal and Chan [56] and Sabherwal and Kirs [57], this paper empirically examines how the effect of antecedent factors on alignment, as well as the effect of alignment on performance, varies across different industries and for different business strategies.

Sabherwal and Chan [56] examined strategic IS alignment as the lack of deviation of a firm's actual IS strategy from the theoretically identified ideal profiles of IS strategy variables appropriate for the firm's business strategy, which was assessed using Miles and Snow's [46] popular typology of Defender, Analyzer, and Prospector strategies. Sabherwal and Chan [56] focused on alignment's implications for firm performance, but did not examine the antecedents of alignment. This paper extends their use 
TABLE I

ANTECEDENTS OF BUSINESS-IS ALIGNMENT ${ }^{\mathrm{a}}$ IN PRIOR LITERATURE

\begin{tabular}{|c|c|c|c|c|}
\hline Study & $\begin{array}{l}\text { Nature of Empirical } \\
\text { Research }\end{array}$ & $\begin{array}{l}\text { Nature of Business-IS } \\
\text { Alignment }\end{array}$ & Antecedents of Alignment & $\begin{array}{l}\text { Related Antecedents in } \\
\text { This Paper }\end{array}$ \\
\hline \multirow{3}{*}{$\begin{array}{l}\text { Sabherwal and } \\
\text { Kirs [57] }\end{array}$} & \multirow{3}{*}{$\begin{array}{l}\text { Questionnaire survey } \\
\text { of } 244 \text { academic } \\
\text { institutions }\end{array}$} & \multirow{3}{*}{$\begin{array}{l}\text { Alignment between critical } \\
\text { success factors and IT } \\
\text { capability }\end{array}$} & Environmental uncertainty & Environmental uncertainty \\
\hline & & & Organizational integration & Planning sophistication \\
\hline & & & IT management sophistication & No direct link \\
\hline \multirow{6}{*}{$\begin{array}{l}\text { Luftman, Papp, } \\
\text { and Brier [43] }\end{array}$} & \multirow{6}{*}{$\begin{array}{l}\text { Data from 1,051 } \\
\text { business and IT } \\
\text { executives } \\
\text { participating in } \\
\text { classes on alignment }\end{array}$} & \multirow{6}{*}{$\begin{array}{l}\text { Alignment of IT plans with } \\
\text { business plans }\end{array}$} & IT's involvement in strategy development ${ }^{\mathrm{b}}$ & Planning sophistication \\
\hline & & & IT's understanding of business & Shared domain knowledge \\
\hline & & & IT's failure to meet commitments & Prior IS success \\
\hline & & & Senior executive support for IT & No direct link \\
\hline & & & Well-prioritized IT projects & No direct link \\
\hline & & & Business-IT partnerships & No direct link \\
\hline \multirow{4}{*}{$\begin{array}{l}\text { Reich and } \\
\text { Benbasat [54] }\end{array}$} & \multirow{4}{*}{$\begin{array}{l}57 \text { interviews in } 10 \\
\text { business units }\end{array}$} & \multirow{4}{*}{$\begin{array}{l}\text { The social dimension of } \\
\text { business-IT alignment }\end{array}$} & Shared domain knowledge & Shared domain knowledge \\
\hline & & & Successful IT history & Prior IS success \\
\hline & & & Connections between business and IT planning & Planning sophistication \\
\hline & & & Communication between business and IT executives & No direct link \\
\hline \multirow{3}{*}{$\begin{array}{l}\text { Hussin, King, } \\
\text { and Cragg [29] }\end{array}$} & \multirow{3}{*}{$\begin{array}{l}\text { Questionnaire survey } \\
\text { of } 256 \text { small } \\
\text { manufacturing firms }\end{array}$} & \multirow{3}{*}{$\begin{array}{l}\text { The alignment between the } \\
\text { contents of business and IT } \\
\text { strategies }\end{array}$} & CEO commitment to IT & Shared domain knowledge \\
\hline & & & IT sophistication ${ }^{\mathrm{C}}$ & No direct link \\
\hline & & & External IT expertise & No direct link \\
\hline $\begin{array}{l}\text { Kearns and } \\
\text { Lederer [34] }\end{array}$ & $\begin{array}{l}\text { Questionnaire survey } \\
\text { of } 161 \text { firms }\end{array}$ & $\begin{array}{l}\text { Processes and outcomes } \\
\text { related to business-IT alignment }\end{array}$ & Information intensity of the value chain & No direct link \\
\hline
\end{tabular}

a In this Table, we focus on empirical studies that are related to alignment between business strategy and IS strategy, while excluding: (a) conceptual articles that have examined factors affecting alignment; and (b) empirical studies that have examined alignment between other aspects, such as between business strategy and the structure of the IS organization.

b A large number of enablers and inhibitors were identified by the informants in this study. The top four enablers and the top four inhibitors, which included two aspects common (with opposite wording) to both lists, are included in this Table.

c This included sophistication of both IT use and IT management. The latter is related to planning sophistication in this paper.

of the data by examining the antecedents that lead to alignment between firm and IS strategy.

This paper also differs from Sabherwal and Kirs [57] in several ways. Whereas Sabherwal and Kirs focused on the alignment between critical success factors ${ }^{1}$ and IT capability, this paper examines the alignment between business strategy and IS strategy. Business strategy is related to, but different from, critical success factors, and IS strategy is related to, but different from, IT capability. Also, whereas Sabherwal and Kirs [57] examined alignment using a data-driven, nontheoretical approach, this paper employs the theory-based, deductive approach used by Sabherwal and Chan. Moreover, it extends Sabherwal and Kirs' use of the data by examining the effects of a more comprehensive set of factors on alignment.

The theoretical model is described in the next section. The subsequent section provides an overview of the data collection and analyses. This is followed by a presentation of the paper's key findings. Next, the implications of these findings and directions for future research are articulated. We close by highlighting this paper's contributions.

\section{THEORETICAL MODEL}

Several possible antecedents of alignment have been empirically examined before, as summarized in Table I. This paper examines the effects of five factors, four of which-shared domain knowledge, planning sophistication, prior IS success, and environmental uncertainty-are directly based on prior empirical research on alignment. The effect of the fifth factor-organization size—on alignment between business and IS strategies

\footnotetext{
${ }^{1}$ Critical success factors are defined as the limited number of areas in which success is needed to ensure organizational performance [57].
}

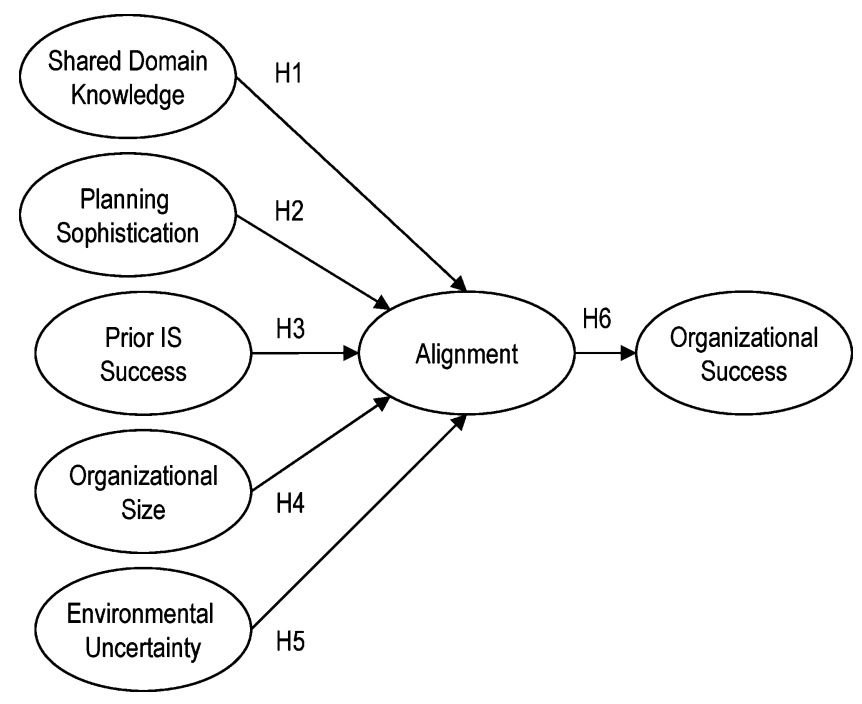

Fig. 1. Theoretical model.

has not, to the best of our knowledge, been empirically examined, although several authors [1], [10], [21], [27], [40] have mentioned it as a possible antecedent. Our selection of these five antecedent factors is a result of their prior discussion in the literature, as well as the nature of data available from the Sabherwal and Chan [56] and Sabherwal and Kirs [57] studies.

In addition to the factors affecting alignment between business and IS strategies, the theoretical model includes the effects of alignment on organizational performance, which has previously been discussed by several authors [4], [9], [11], [16], [20], [29], [34], [42], [43], [55], [67]. Fig. 1 presents the theoretical model which is based on prior empirical studies and theoretical arguments. 
Although the theoretical model is consistent with prior research on alignment between business and IS strategies, it is important to note some departures from the prior literature. First, this paper extends the current literature by explicitly examining the extent to which the results related to this theoretical model hold across firm strategies and industries. We explore the extent to which previous findings can be confirmed empirically and provide insights into why previously reported findings may have appeared contradictory. Second, in examining these relationships, this paper tests an integrated model-including the effects of antecedents on alignment as well as the effect of alignment on organizational performance-unlike most of the prior literature, which has either examined the performance effects of alignment or the antecedents of alignment. Third, as Table I indicates, the use of the five antecedent factors represents a more comprehensive assessment of the factors affecting alignment between business strategy and IS strategy than previously conducted in a theory-based empirical study. ${ }^{2}$ Finally, this paper employs a theory-based view of alignment, instead of asking informants to simply indicate whether business strategy and IS strategy are aligned.

The rest of the theoretical development is organized as follows. The first five subsections examine the effects of the five antecedent factors-shared domain knowledge, planning sophistication, prior IS success, organizational size, and environmental uncertainty-on alignment. The sixth subsection examines the effect of alignment on organizational performance. The last subsection examines the differences across business strategies.

\section{A. Shared Knowledge Between Business and IS Executives}

Research on strategic IS planning [32], [61], [66] highlights the importance of the top managers' and IS managers' knowledge of IT and business strategy. When business and IS executives are knowledgeable about the business and IT, they are more likely to develop shared understanding and vision [20], and achieve improved linkages between objectives and actions [55]. Vitale et al. [67] demonstrate that top managers' lack of knowledge of IT inhibits alignment, while Luftman and Brier [42] discuss how IS executives' understanding of business issues enables alignment. Sambamurthy and Zmud [58] and Bassellier et al. [3] emphasize the importance of business executives' familiarity with IS, technologies, and their potential business impacts. IT-knowledgeable top managers are likely to participate more fully in IS planning and show greater support for IS [32], [37]; this in turn fosters alignment [42].

Consistent with these arguments, Reich and Benbasat [55, p. 86] found shared domain knowledge, which they define as "the ability of IT and business executives, at a deep level, to understand and be able to participate in the other's key processes and to respect each other's unique contribution and challenges," to facilitate short-term and long-term alignment. This highlights

\footnotetext{
${ }^{2}$ One prior study [43] included a large number of enablers and inhibitors of alignment, but these were identified by the study informants rather than by the authors based on prior theory.
}

the importance for managers of common goals, common experiences, common vocabulary and even common, overlapping education.

Hypothesis 1: Shared knowledge between business and IS executives is positively related to alignment.

\section{B. Strategic Planning Processes}

Since the 1970s, the literature on strategic systems has highlighted the importance of sophisticated (i.e., well-defined and comprehensive) strategic planning processes [31]. Raghunathan and Raghunathan [51, p. 126] argue that planning ("the discipline and vision to foresee problems and opportunities within a turbulent and complex environment,") is one of the most important IS management issues; it is frequently ranked by IS practitioners among the top ten key issues. Sophisticated business planning and IS planning processes bring business and IS executives together repeatedly in an attempt to manage technology-related opportunities and challenges. This ongoing communication helps to improve IS alignment.

Lederer and Mendelow [37], Vitale et al. [67], and Wang and Tai [68] have argued that IS strategy cannot be aligned to the business strategy when the organization lacks a formal planning process and the business strategy is ambiguously defined. Luftman and Brier [42] also found clearly defined business goals and visions to facilitate alignment. Other researchers have explored how planning processes promote shared knowledge and alignment between IS and business strategy [9], [10], [48]. Thus, prior research suggests that managers need sophisticated strategic planning processes in order to facilitate alignment. In the current study, we test to see if this is always the case.

Hypothesis 2: Planning sophistication is positively related to alignment.

\section{IS Department Track Record}

Past implementation failures, that is previous IS projects that were not perceived to have been successful, influence top management's ongoing perceptions of IT [44]. Martins and Kambil [44] argue that how managers view new or future strategic IS opportunities is affected by their looking back at experiences with past ones. As a result of past system failures, IS may lose credibility with top management and end-users [38], [43]. Alternatively, successful IT implementation may improve the relationship between IT and other functional areas [7], [44]. IS colleagues who are perceived to be competent are more likely to be trusted and consulted early in decision-making processes. As a result, they are more likely to be aware of new business developments and to act in accordance with current and emerging business needs.

Luftman and Brier [42] found that the IS group's track record, i.e., its ability to meet its previous commitments, facilitated alignment. Reich and Benbasat [55] also found prior IS project success to facilitate short-term alignment. Thus, prior IS success is another important predictor of current levels of alignment. This suggests that past credibility gaps cannot be 
ignored by managers but must be addressed as a high priority. Using new successes to improve its track record should enable the IS organization to better align itself, as a trusted partner, with the rest of the organization.

Hypothesis 3: Prior IS success is positively related to alignment.

\section{Organizational Size}

Organizational size (commonly measured in terms of employees and revenues) affects alignment partly through its influence on IT governance [10], [40]. Small and medium-sized firms tend to be structured around functions, e.g., IS, accounting, or marketing, and use centralized structures to coordinate subunits [1], [21]. This central coordination generally limits the need for other explicit mechanisms to promote functional alignment, and the negative impact of lack of alignment. Large firms, however, tend to create divisions along product lines and use decentralized governance structures to coordinate divisional activities [23]. This makes task-level coordination more difficult and thereby accentuates the need for explicit mechanisms to promote strategic alignment [1]. Hence, the larger the organization, the more commonly do managers introduce formal processes and structures to ensure alignment [27].

Also, large firms generally have more organizational slack that managers can use to invest in aligning business and IS strategies [16]. They have the resources to focus more wealth on identifying and implementing technologies that support business strategy. Therefore, although the centralized structures of smaller firms provide some inherent advantages with respect to alignment, overall, because of slack and managerial action, we expect size and alignment to be positively related. In this study, we examine the extent to which this hypothesis is supported across different industries and firm strategies.

Hypothesis 4: Organizational size is positively related to alignment.

\section{E. Environmental Uncertainty}

Alignment is also influenced by factors beyond the organization's control. Previous IS strategy research considers uncertainty in the environment to predict strategic IS use [4], [10], [64], [66]. Environmental uncertainty-involving the degree of change and instability in the firm's environment, and the usefulness of data related to the current state of the environment, potential impact of developments, and strategic options available [41] - increases the need for information processing [17], [23] and the importance of the firm's information systems.

IT can enable organizations in uncertain environments to acquire, store, process and use information. Organizations respond to uncertainty by using IT to increase their information-processing capabilities and create electronic ties with customers and suppliers [39]. Managers in organizations in turbulent environments are, therefore, expected to invest more fully in IT and to place greater reliance on IT. It is expected that they will increase the attention given to the alignment of IT and business strategies [26], [32].

Hypothesis 5: Environmental uncertainty is positively related to alignment.

\section{F. Effect of Alignment on Organizational Performance}

Alignment implies a shared vision of, commitment to, and plan for addressing, areas considered critical to success [56]. The last hypothesis tests the common belief that alignment is related to organizational performance [11], [18], [30], [35], [38]. Here, performance refers to effectiveness or success relative to the competition [11].

Lederer and Mendelow [38, p. 526] argue that alignment between IS and firm strategic plans should increase a firm's ability "to realize its goals and objectives." When executives value and understand the importance of each other's contributions, communicate regularly and move toward shared goals, they are likely to experience improved managerial outcomes. These arguments suggest that alignment leads to more focused and strategic use of IS and, consequently, improved performance [50], [60]. Although it is commonly assumed that this hypothesis is true, it is included here so that we may explicitly examine the empirical support for this statement across multiple industries and firms.

Hypothesis 6: Alignment is positively related to organizational performance.

\section{G. Differences Across Business Strategies}

As mentioned earlier, Fig. 1 summarizes the theoretical model, including the above hypotheses. An important research objective pursued in this paper is to understand whether this model applies equally well across different types of industries, organizations and strategies [49], [52]. Here, our thinking is that the firm context (e.g., the extent to which an industry is information-intensive and the extent to which IT is regarded as a strategic resource) can influence the importance of relationships in the research model (e.g., the importance of IS alignment for overall firm performance) [25]. Similarly, the importance of IS alignment can vary depending on the firm's competitive strategy [56]. The differences across organizations were examined in this research by focusing on business firms in one study and on academic institutions in the other. The differences across business strategies were examined using Miles and Snow's [46] typology of Defender, Prospector, and Analyzer ${ }^{3}$ business strategies. Although other business strategy measurement approaches have been examined in the IS literature, e.g., [11], the Miles and Snow typology is perhaps the most commonly used and the best understood [71]. To maximize the value and understanding of our research findings, we employ it in this paper also.

Organizations pursuing the Defender business strategy concentrate on a stable and predictable but narrow niche in their industries by offering high quality but standard products or services at low prices. Emphasizing operational efficiency and economies of scale, these organizations generally employ a mechanistic organization structure. Being the most stable of

\footnotetext{
${ }^{3}$ Miles and Snow [46] also described a fourth type of organization (Reactors), but considered it to be an organization that either lacks a viable strategy or is in transition from one of the three strategies to another. According to Zahra and Pearce [71, p. 752], "Reactors do not follow a conscious strategy."We, therefore, excluded Reactors, as has commonly been done in prior empirical studies on Miles and Snow's typologies (e.g., [19] and [56]).
} 
TABLE II

SURVEY RESPONDENTS

\begin{tabular}{|l|r|r|r|}
\hline Study 1 & & & \\
\hline Business Strategy Questionnaire & Study 1a & Study 1b & Combined \\
\hline President/Acting President & 74 & 11 & 85 \\
\hline Vice President & 65 & 27 & 92 \\
\hline Chief Operating Officer & 1 & 1 & 2 \\
\hline Chief Financial Officer & 0 & 5 & 5 \\
\hline Director & 6 & 6 & 12 \\
\hline Controller & 1 & 4 & 5 \\
\hline Manager & 9 & 8 & 17 \\
\hline Missing & 8 & 0 & 8 \\
\hline Total & 164 & 62 & 226 \\
\hline
\end{tabular}

\begin{tabular}{|c|c|c|c|}
\hline Study 1 & & & \\
\hline IS Strategy Questionnaire & Study 1a & Study $1 \mathrm{~b}$ & Combined \\
\hline $\begin{array}{l}\text { Chief Information Officer, Executive Vice President, Senior } \\
\text { Vice President, or Vice President }\end{array}$ & 115 & 23 & 138 \\
\hline Chief Financial Officer & 1 & 2 & 3 \\
\hline Senior Director/Director & 21 & 12 & 33 \\
\hline Controller & 3 & 6 & 9 \\
\hline $\begin{array}{l}\text { General Manager/Manager/ } \\
\text { Assistant Vice President }\end{array}$ & 18 & 17 & 35 \\
\hline Superintendent & 1 & 1 & 2 \\
\hline Missing & 5 & 1 & 6 \\
\hline Total & 164 & 62 & 226 \\
\hline
\end{tabular}

\begin{tabular}{|l|r|}
\hline Study 2 & \\
\hline $\begin{array}{l}\text { Senior Vice President, Vice President, Provost, Vice Provost, } \\
\text { Chancellor, Vice Chancellor }\end{array}$ & 110 \\
\hline Director, Executive Director & 44 \\
\hline $\begin{array}{l}\text { Associate/Assistant Vice President, Associate/Assistant } \\
\text { Provost, Associate/Assistant Vice Provost }\end{array}$ & 39 \\
\hline Others & 23 \\
\hline Missing & 28 \\
\hline Total & 244 \\
\hline
\end{tabular}

the three kinds of organizations, they do not tend to search outside their domain for new opportunities, and rarely make major adjustments in their structure or technology.

Prospectors are quite different. They continuously seek new product/market opportunities, and are the creators of change in their market. Emphasizing innovativeness, they function in a broad and dynamic domain, and employ an organic organization structure. However, their concern with flexibility and innovativeness often results in control and operational efficiency being compromised.

Finally, organizations pursuing the Analyzer business strategy share some characteristics with organizations pursuing each of the other two strategies. Analyzer organizations maintain a stable domain of core products, while seeking new product/market opportunities. They rarely initiate new products, but often follow the Prospector by quickly introducing competitive, and possibly better, products. To simultaneously address the conflicting demands of efficiency and innovation, these organizations generally employ a matrix organization structure, and a dual technological core with stable and flexible components.

The more stable nature of the Defender would make it easier to achieve alignment as compared to Prospectors. Alignment between business and IS strategies might, therefore, provide less advantage to organizations pursuing a Defender strategy, as compared to organizations pursuing Analyzer or Prospector strategies. However, no formal hypotheses were proposed due to the paucity of prior literature concerning the nature of possible relationships between business strategies and alignment.

Our use of Miles and Snow's [46] typology of business strategies was influenced by two important considerations. First, as mentioned earlier, this typology of business strategies is widely accepted in the business strategy and IS literature. This is reflected in the fact that Zahra and Pierce [71] examined 17 empirical investigations of Miles and Snow's business strategies, and several additional publications have further examined this typology since Zahra and Pierce's survey [19], [26], [33], [56]. Second, consistent with Sabherwal and Chan [56], the typology provides a theoretical base for our empirical assessment of alignment between business strategy and IS strategy.

\section{EMPIRICAL DATA}

We use data from two empirical studies, including three separate surveys, to test the theoretical model in several independent settings. Study 1 focused on business firms in four industries, while Study 2 focused on very different (public and private academic) institutions. Each research instrument was developed through rigorous pretesting and revision. Table II provides survey respondents' characteristics. Table III presents characteristics of the organizations studied. Appendix A provides the measures used in the two studies. 
TABLE III

SOME CHARACTERISTICS OF THE ORGANIZATIONS STUDIED

\begin{tabular}{|c|c|c|c|}
\hline \multirow{2}{*}{$\begin{array}{l}\text { Study } 1 \\
\text { Industry }\end{array}$} & \multicolumn{3}{|c|}{ Frequencies } \\
\hline & Study 1a & Study 1b & Combine \\
\hline Pharmaceutical Manufacturing & 27 & 29 & 56 \\
\hline Auto Parts Manufacturing & 40 & 17 & 57 \\
\hline Banks & 39 & -- & 39 \\
\hline Insurance & 58 & 16 & 74 \\
\hline Missing Information & 0 & 0 & 0 \\
\hline Total & 164 & 62 & 226 \\
\hline \multicolumn{4}{|l|}{ Total no. of employees } \\
\hline$<300$ & 75 & 23 & 98 \\
\hline $301-700$ & 40 & 19 & 59 \\
\hline $701-1,000$ & 9 & 7 & 16 \\
\hline $1,001-5,000$ & 32 & 11 & 43 \\
\hline $5,001-25,000$ & 5 & 1 & 6 \\
\hline$>25,000$ & 3 & 1 & 4 \\
\hline Missing & 0 & 0 & 0 \\
\hline \multicolumn{4}{|l|}{ Annual revenue (in \$million) } \\
\hline$<20$ & 17 & 9 & 26 \\
\hline $21-50$ & 35 & 10 & 45 \\
\hline $51-100$ & 36 & 6 & 42 \\
\hline $101-500$ & 43 & 24 & 67 \\
\hline $501-1000$ & 15 & 7 & 22 \\
\hline$>1000$ & 16 & 6 & 22 \\
\hline Missing & 2 & 0 & 2 \\
\hline
\end{tabular}

\begin{tabular}{|l|r|}
\hline \multicolumn{2}{|c|}{ Study 2 } \\
\hline Institutional Control \\
\hline Public & 171 \\
\hline Private & 73 \\
\hline Missing & 0 \\
\hline & \\
\hline Highest Degree Offered & 108 \\
\hline Doctorate & 120 \\
\hline Masters & 16 \\
\hline Baccalaureate & 0 \\
\hline Missing & \\
\hline & 43 \\
\hline Total Student Enrollment & 54 \\
\hline 20,000 or more & 68 \\
\hline $10,000-19,999$ & 63 \\
\hline $5,000-9,999$ & 16 \\
\hline Less than 5,000 & \\
\hline Missing & \\
\hline
\end{tabular}

\section{A. Study 1: Business Firms}

Study 1 used data presented in Sabherwal and Chan [56] examining links between alignment and firm performance. The current paper extends this study significantly by examining antecedents to alignment and firm performance. This dataset included two rounds of surveying (hereafter referred to as Studies 1a and 1b) examining firms listed in Dun \& Bradstreet directories in insurance, banking, pharmaceutical, and auto parts industries in the United States and Canada. For the first survey, an introductory letter and follow-up call to the CEO explained the purpose of the study and elicited participation. CEO's were then mailed four questionnaires that examined business strategy, IS strategy, business performance and IS performance. Due to the somewhat modest response rate (19\%) to the first survey, which required the Chief Executive Officer (CEO), Chief Information Officer (CIO), Chief Financial Officer (CFO), and a senior end user in each organization to complete four different questionnaires,${ }^{4}$ only two questionnaires were used in the

\footnotetext{
${ }^{4}$ In Study 1, only firms returning four fully completed, usable questionnaires were considered to have responded.
}

second follow-up survey. In this second survey, the CEO was asked to provide information on business strategy, business performance and IS performance. The CIO was asked to provide information on IS strategy. Although fewer (two versus four) respondents were required per firm, the second study received a slightly lower $(17 \%)$ response, ${ }^{5}$ perhaps due to the greater data and time demands placed on the CEO.

We obtained 164 and 62 complete sets of responses for Study $1 \mathrm{a}$ and Study 1b, respectively. Both surveys included responses from a large number of senior business executives (139 out of 164 respondents in Study 1a and 38 out of 62 in Study 1b were at the level of President, Acting President, or Vice President) and senior IS executives (137 out of 164 respondents in Study $1 \mathrm{a}$ and 40 out of 62 in Study 1b were at the level of CIO, Executive Vice President, Senior Vice President, Vice President, $\mathrm{CFO}$, or Director). Both surveys included responses from pharmaceutical manufacturing (27 in 1a and 29 in 1b), auto-parts manufacturing (40 in 1a and 17 in $1 \mathrm{~b}$ ), and insurance (58 in 1a and 16 in 1b) firms. Study 1a also included 39 responses from banks, but Study $1 \mathrm{~b}$ did not include bank data. The firms studied varied considerably in size, with a number of them (75 in 1a and 23 in 1b) having less 300 employees, and also a number of them (49 in 1a and $20 \mathrm{in} \mathrm{1b)} \mathrm{having} \mathrm{more} \mathrm{than} 700 \mathrm{em}-$ ployees. To assess nonresponse bias, statistics were separately compiled by industry for all companies surveyed, all companies returning questionnaires, and all late arriving questionnaires. A slightly higher early response rate from smaller firms and Canadian firms was detected based on an examination of the means and ranges for two organizational measures (number of employees, annual sales). However, there was no evidence to suggest significant nonresponse bias. Also, based on the means and ranges, no response differences across the four industries could be detected. ${ }^{6}$

\section{B. Study 2: Academic Institutions}

Study 2 used data gathered by Sabherwal and Kirs [57] who examined links between critical success factors and IT capabilities of academic institutions. Questionnaires were mailed to the Vice Presidents of Academic Affairs of the 650 largest (in student enrollment) four-year institutions of higher learning, identified from the Higher Education Directory. A total of 244 respondents returned properly completed questionnaires in the first round.

Respondents had the option of including identifying information, and $216(88.5 \%)$ chose to identify themselves. The respondents included 110 at the level of Chancellor, Vice Chancellor, Senior Vice President, Vice President, Provost, or Vice Provost. The responses were from 171 public and 73 private academic institutions, with 43 institutions having more than 20000 students and 63 having less than 5000 students. To assess nonresponse bias, these academic institutions were compared with 50 randomly selected nonrespondents in terms of

\footnotetext{
${ }^{5}$ Only firms returning two completed surveys were counted in computing the response rate for Study 2.

${ }^{6}$ Formal t-tests could not be conducted due to missing Dun \& Bradstreet data and small sample sizes for companies responding late in a few categories (e.g., pharmaceutical firms in the U.S.).
} 
TABLE IV

THREE STRATEGic CONFIGURATIONS

\begin{tabular}{|c|c|c|c|c|c|c|c|c|c|c|c|c|}
\hline & \multicolumn{12}{|c|}{ Frequencies for Study 1} \\
\hline Industry & \multicolumn{3}{|c|}{ Defenders } & \multicolumn{3}{|c|}{ Prospectors } & \multicolumn{3}{|c|}{ Analyzers } & \multicolumn{3}{|c|}{ Total } \\
\hline & S1a & S1b & $\mathrm{C}$ & S1a & S1b & $\mathrm{C}$ & S1a & S1b & $C$ & S1a & S1b & $\mathrm{C}$ \\
\hline $\begin{array}{l}\text { Pharmaceutical } \\
\text { Manufacturing }\end{array}$ & 6 & 4 & 10 & 10 & 11 & 21 & 11 & 14 & 25 & 27 & 29 & 56 \\
\hline $\begin{array}{l}\text { Auto Parts } \\
\text { Manufacturing }\end{array}$ & 10 & 5 & 15 & 11 & 7 & 18 & 19 & 5 & 24 & 40 & 17 & 57 \\
\hline Banking & 9 & 0 & 9 & 14 & 0 & 14 & 16 & 0 & 16 & 39 & 0 & 39 \\
\hline Insurance & 11 & 3 & 14 & 20 & 5 & 25 & 27 & 8 & 35 & 58 & 16 & 74 \\
\hline Total & 36 & 12 & 48 & 55 & 23 & 78 & 73 & 27 & 100 & 164 & 62 & 226 \\
\hline
\end{tabular}

\begin{tabular}{|l|c|c|c|c|}
\hline $\begin{array}{l}\text { Perceived Business } \\
\text { Performance }\end{array}$ & $\begin{array}{c}\text { Defenders } \\
\text { Mean (S.D.) }\end{array}$ & $\begin{array}{c}\text { Prospectors } \\
\text { Mean (S.D.) }\end{array}$ & $\begin{array}{c}\text { Analyzers } \\
\text { Mean (S.D.) }\end{array}$ & $\begin{array}{c}\text { Total } \\
\text { Mean (S.D.) }\end{array}$ \\
\hline - Study 1a & $3.24(0.62)$ & $3.34(0.60)$ & $3.38(0.68)$ & $3.33(0.64)$ \\
\hline - Study 1b & $3.52(0.60)$ & $3.64(0.69)$ & $3.71(0.43)$ & $3.65(0.57)$ \\
\hline - Combined Study 1 & $3.31(0.62)$ & $3.43(0.64)$ & $3.47(0.64)$ & $3.42(0.63)$ \\
\hline
\end{tabular}

\begin{tabular}{|l|c|c|c|c|c|c|c|c|c|c|c|c|}
\hline & \multicolumn{9}{c|}{ Frequencies for Study 2 } \\
\hline Industry & \multicolumn{3}{|c|}{ Defenders } & \multicolumn{3}{c|}{ Prospectors } & \multicolumn{3}{c|}{ Analyzers } & \multicolumn{3}{c|}{ Total } \\
\hline & Pub & Priv & All & Pub & Priv & All & Pub & Priv & All & Pub & Priv & All \\
\hline Academic Institution & 104 & 42 & 146 & 18 & 13 & 31 & 19 & 6 & 25 & 141 & 61 & 202 \\
\hline
\end{tabular}

\begin{tabular}{|l|c|c|c|c|}
\hline $\begin{array}{l}\text { Perceived Business } \\
\text { Performance }\end{array}$ & $\begin{array}{c}\text { Defenders } \\
\text { Mean (S.D.) }\end{array}$ & $\begin{array}{c}\text { Prospectors } \\
\text { Mean (S.D.) }\end{array}$ & $\begin{array}{c}\text { Analyzers } \\
\text { Mean (S.D.) }\end{array}$ & $\begin{array}{c}\text { Total } \\
\text { Mean (S.D.) }\end{array}$ \\
\hline - Study 2 & $3.56(1.55)$ & $4.07(1.40)$ & $3.08(1.43)$ & $3.58(1.54)$ \\
\hline
\end{tabular}

\author{
Legend: \\ S1a: Study 1a \\ S1b: Study $1 \mathrm{~b}$ \\ C: Combined S1a and S1b \\ Pub: Public \\ Priv: Private
}

seven attributes: total student enrollment, student-faculty ratio, average SAT score (verbal), average SAT score (mathematics), Gourman's rating (undergraduate), Gourman's rating (graduate), and Barron's rating. None of these seven comparisons was statistically significant $(p<.05)$.

\section{ANALYSIS AND RESULTS}

\section{A. Classification and Alignment}

We used Miles and Snow's typology [46] of Defender, Analyzer, and Prospector to classify organizations. As business and IS strategies are multi-dimensional constructs [46], the alignment of these strategies should be examined using rich, multi-dimensional conceptualizations. We used the approach employed by Sabherwal and Chan [56], which utilizes profile deviation [65] along with the identification of ideal business and IS strategies based on prior theory [63]. Alignment was calculated by measuring the deviation of an organization's actual IS strategy from the IS strategy that is theoretically ideal for its business strategy. IS strategy was measured in terms of four types of systems (operational support systems, market information systems, strategic decision support systems, and interorganizational systems [56]), whereas business strategy was measured in terms of Prospector, Analyzer, and Defender strategies. We also used the ideal alignment pattern that was employed by Sabherwal and Chan [56]. Three steps were used to compute alignment: 1) normalization of research variables within each industry in each survey; 2) classification of organizations into Defenders, Prospectors, and Analyzers; and 3) calculation of alignment between business and IS strategies. Appendix B summarizes the specific tasks within each step.

Table IV presents information on the results of our classification of organizations. In Study 1, 48, 78, and 100 firms are closest to the ideal types identified by Miles and Snow [46] as Defenders, Prospectors, and Analyzers, respectively. A chi-square test $\left(\chi^{2}=0.32\right.$, degrees of freedom $=2$; $p>0.10)$ revealed that the distributions do not differ significantly across Study 1a (36 Defenders, 55 Prospectors, 73 Analyzers) and Study 1b (12 Defenders, 23 Prospectors, 27 Analyzers); the higher proportion of Analyzers is consistent with prior strategy research [45], [70]. Study 2 found 146 Defenders, 31 Prospectors, and 25 Analyzers. This distribution of strategies differed significantly from Study 1 $\left(\chi^{2}=113.78\right.$, degrees of freedom $\left.=2 ; p<0.01\right)$, but is supported by previous literature indicating that nonprofit and public organizations adopt more conservative strategies when compared with their for-profit counterparts [44], [46]; Study 1 did not include any public firms, but Study 2 included 171 public academic institutions. 
TABLE V

RELIABILITIES AND CORRELATIONS ${ }^{\mathrm{a}}$

\begin{tabular}{|c|c|c|c|c|c|c|c|c|}
\hline & & \multirow{2}{*}{$\begin{array}{l}\text { Indicators' } \\
\text { Composite } \\
\text { Reliability }\end{array}$} & \multicolumn{6}{|c|}{ Correlations of Constructs and Average Variance Extracted } \\
\hline & & & OSUC & ALIGN & SDK & SOPH & PRIOR & SIZE \\
\hline \multirow{7}{*}{ 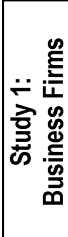 } & Organizational Success (OSUC) & - & - & & & & & \\
\hline & Alignment (ALIGN) & - & 0.17 & - & & & & \\
\hline & Shared Domain Knowledge (SDK) & 0.92 & 0.33 & 0.13 & 0.82 & & & \\
\hline & Planning Sophistication (SOPH) & 0.77 & 0.15 & 0.11 & 0.27 & 0.79 & & \\
\hline & Prior IS Success (PRIOR) & 0.87 & 0.09 & 0.11 & 0.19 & 0.15 & 0.84 & \\
\hline & Organizational Size (SIZE) & - & 0.01 & 0.23 & 0.01 & 0.04 & 0.08 & - \\
\hline & Environmental Uncertainty (UNC) & - & 0.05 & 0.02 & 0.01 & 0.19 & 0.12 & 0.10 \\
\hline \multirow{7}{*}{ 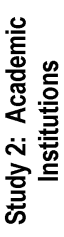 } & Organizational Success & ـ & - & & & & & \\
\hline & Alignment & - & 0.19 & - & & & & \\
\hline & Shared Domain Knowledge & 0.88 & 0.10 & 0.29 & 0.90 & & & \\
\hline & Planning Sophistication & 0.76 & 0.03 & 0.15 & 0.30 & 0.76 & & \\
\hline & Prior IS Success & 0.85 & 0.06 & 0.28 & 0.45 & 0.22 & 0.89 & \\
\hline & Organizational Size & - & 0.30 & 0.07 & 0.00 & 0.11 & 0.05 & - \\
\hline & Environmental Uncertainty & - & 0.11 & 0.16 & 0.04 & 0.21 & 0.10 & 0.10 \\
\hline
\end{tabular}

aDiagonal elements in the "correlation of constructs" matrix are the square root of the AVE. For adequate discriminant validity, diagonal elements should be greater than corresponding off-diagonal elements.

\section{B. Empirical Tests}

To test the research model, we used PLS, a structural equation modeling (SEM) technique [2]. When compared with other SEM techniques, PLS imposes minimal demands on sample size [69]. PLS data requirements are ten times either: 1) the construct with the greatest number of indicators or 2) the construct with the greatest number of antecedents. Also, because PLS focuses on explaining variance, methodologists suggest using it to analyze complex models, even when there is little well-established theory [12], [15]. Both measurement (i.e., construct validity) and structural (i.e., hypothesis testing) models were estimated using PLS-Graph 2.91 [14]. We describe our analysis in two steps, focusing first on the measurement model and then on the structural model.

The Measurement Model: Table V presents reliabilities, correlations, and average variance extracted explained in the measurement model. The average variance extracted (AVE) measures the variance captured by the indictors relative to measurement error [22], and it should be greater than 0.50 [2]. The measurement model integrates reflective and formative measures of the research variables. For reflective constructs, indicators are an effect of the underlying construct and are assumed to be correlated [2]. For example, planning sophistication influences how firms formulate strategy, conduct research, and coordinate activities between firm functions. When planning sophistication's value shifts, its indicators will demonstrate a proportionate shift in value. For formative constructs, indicators form or cause the latent construct and are assumed to be uncorrelated [2]. In this paper, environmental uncertainty and firm size are operationalized formative. Firm size is operationalized as a function of number of employees and annual revenue in millions. Environmental conditions are operationalized as a function of changes in external conditions. As external conditions such as competitor moves or regulations change, the amount of environmental uncertainty will display a corresponding shift. Hence, a formative construct's value shifts in response to change in any of its indicators' values.

When using PLS to assess construct reliability and validity, methodologists recommend calculating the AVE and indicators' composite reliability (ICR) for each construct [13]. AVE measures the variance captured by the indicators relative to the measurement error [22]. In both studies, AVE values for all reflective constructs exceeded the recommended cutoff level of 0.50 [13]. Composite reliability is calculated by squaring the sum of loadings, then dividing this by the sum of squared loadings, and adding the sum of the error terms [67]. Interpreted like a Cronbach's alpha, an ICR of 0.70 is considered satisfactory [22]. Based on the item loadings, ${ }^{7}$ ICR values for shared knowledge, planning sophistication, and prior IS success were satisfactory in both studies, as shown in Table V. ICR values could not be computed for alignment and organizational performance, which used computed measures, and for environmental uncertainty and organizational size, which were measured using formative indicators.

Discriminant and convergent validities indicate whether the measures of constructs are distinct and the various indicators load on intended constructs. To evaluate discriminant validity, Fornell and Larcker [22] suggest comparing AVE with the square of the correlations among the latent variables. The correlations among indicators of a construct should be greater than across constructs. The item correlations (see Table V) demonstrate discriminant validity for the constructs in each subgroup. Factor loadings (see Table VI) also help assess discriminant validity [13]; each indicator should load higher on the construct it measures than on other constructs. Our

\footnotetext{
${ }^{7}$ Appendix A provides detailed information on the items and their psychometric properties.
} 
TABLE VI

LOADINGS AND CROSS LOADINGS FOR THE REFLECTIVE RESEARCH VARIABLES ${ }^{a}$

\begin{tabular}{|l|c|c|c|}
\hline \multicolumn{5}{|c|}{ Study 1 } \\
\hline & $\begin{array}{c}\text { Shared Domain } \\
\text { Knowledge } \\
\text { (SDK) }\end{array}$ & $\begin{array}{c}\text { Strategic } \\
\text { Plans }\end{array}$ & $\begin{array}{c}\text { Prior IS } \\
\text { Success } \\
\text { (Prior) }\end{array}$ \\
\hline SDK1 & $\mathbf{0 . 8 1}$ & 0.22 & 0.17 \\
\hline SDK2 & $\mathbf{0 . 6 9}$ & 0.16 & 0.04 \\
\hline SOPH1 & 0.02 & $\mathbf{0 . 7 7}$ & 0.25 \\
\hline SOPH2 & 0.14 & $\mathbf{0 . 6 2}$ & 0.13 \\
\hline SOPH3 & 0.23 & $\mathbf{0 . 8 1}$ & 0.05 \\
\hline PRIOR1 & 0.17 & 0.13 & $\mathbf{0 . 9 6}$ \\
\hline PRIOR2 & 0.27 & 0.20 & $\mathbf{0 . 7 5}$ \\
\hline
\end{tabular}

\begin{tabular}{|l|c|c|c|}
\hline \multicolumn{4}{|c|}{ Study 2 } \\
\hline & $\begin{array}{c}\text { Shared Domain } \\
\text { Knowledge } \\
\text { (SDK) }\end{array}$ & $\begin{array}{c}\text { Strategic } \\
\text { Plans }\end{array}$ & $\begin{array}{c}\text { Prior IS } \\
\text { Success } \\
\text { (PRIOR) }\end{array}$ \\
\hline SDK1 & $\mathbf{0 . 8 9}$ & 0.27 & 0.50 \\
\hline SDK2 & $\mathbf{0 . 8 9}$ & 0.26 & 0.30 \\
\hline SOPH1 & 0.17 & $\mathbf{0 . 6 0}$ & 0.20 \\
\hline SOPH2 & 0.23 & $\mathbf{0 . 7 6}$ & 0.15 \\
\hline SOPH3 & 0.23 & $\mathbf{0 . 7 6}$ & 0.13 \\
\hline PRIOR1 & 0.33 & 0.12 & $\mathbf{0 . 8 7}$ \\
\hline PRIOR2 & 0.46 & 0.26 & $\mathbf{0 . 8 9}$ \\
\hline
\end{tabular}

${ }^{\mathrm{a}}$ External environment and size were not included in the discriminant analysis because they use formative indicators [12, p. 327].

TABLE VII

ITEM WEIGHTS AND LOADINGS FOR THE FORMATIVE RESEARCH VARIABLES ${ }^{a}$

\begin{tabular}{|l|l|c|c|}
\hline \multicolumn{3}{|c|}{ Study 1 Item Weights and Loadings } \\
\hline Indicator & \multicolumn{1}{|c|}{ Environmental Uncertainty } & Weights & Loading \\
\hline UNC1 & Customer preferences and demand patterns. & $0.34^{* *}$ & $0.34^{* *}$ \\
\hline UNC2 & Competitor moves. & $0.48^{* *}$ & $0.60^{* *}$ \\
\hline UNC3 & $\begin{array}{l}\text { Regulatory or legislative influences } \\
\text { (nonsignificant). }\end{array}$ & 0.07 & $0.30^{*}$ \\
\hline
\end{tabular}

\begin{tabular}{|l|l|c|c|}
\hline \multicolumn{4}{|c|}{ Study 2 Item Weights and Loadings } \\
\hline Indicator & \multicolumn{1}{|c|}{ Environmental Uncertainty } & Weights & Loading \\
\hline UNC1 & Changing demands for courses. & $0.53^{* *}$ & $0.50^{* *}$ \\
\hline UNC2 & Innovations by similar institutions. & $0.49^{* *}$ & $0.44^{* *}$ \\
\hline UNC3 & Government action and interference. & $0.36^{* *}$ & $0.32^{* *}$ \\
\hline
\end{tabular}

\section{** Significant at .01}

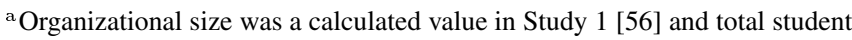
enrollment at the academic institution in Study 2 [57].

results demonstrated satisfactory discriminant and convergent validities for each reflective construct.

For formative constructs, such as environmental uncertainty, traditional methods of assessing reliability such as internal consistency (e.g., composite reliability) and validity (e.g., AVE) are not appropriate [6]. In lieu of traditional methods, examining the significance of item weights is recommended [13]. Based on this examination (see Table VII), the indicator of regulatory change from Study 1 was omitted from the analysis. The remaining two indicators of uncertainty in Study 1, and all three indicators in Study 2, were significant.

The Structural Model: Unlike covariance based estimation methods such as maximum-likelihood (ML) structural equation modeling, PLS does not provide global measures of model fit

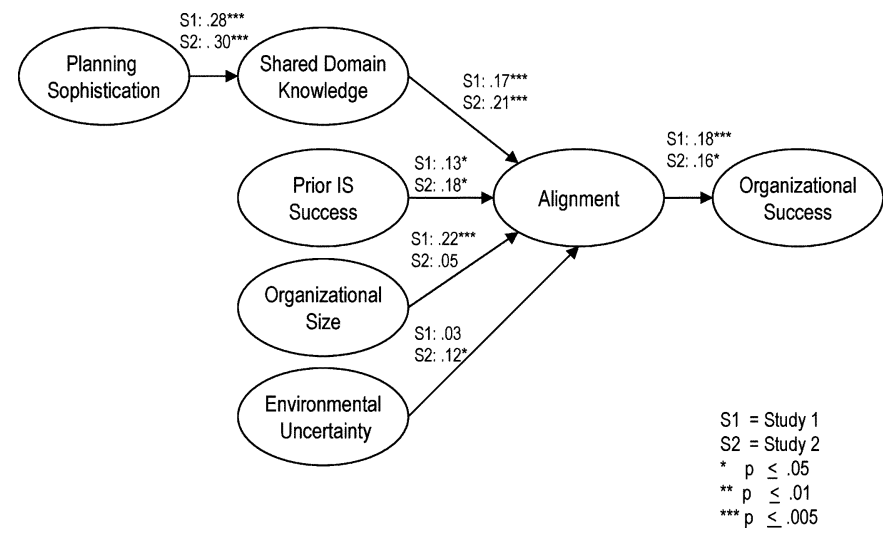

Fig. 2. Revised model.

[28]. Where ML SEM estimation techniques focus on maximizing model fit to the observed covariance matrix, PLS focuses on maximizing the variance explained for all the endogenous constructs in the research model. Rather than model fit, PLS models are evaluated based on the significance of hypothesized relationships and the variance explained in each endogenous construct, which is assessed using the $R^{2}$ value, and should be interpreted in a manner similar to that used in multiple regression analysis [53].

The structural model results provided modest support for the theoretical model, especially with respect to alignment in Study 1. We did not find a significant relationship from planning sophistication to alignment. Because the literature also suggests that planning sophistication should influence understanding and knowledge sharing amongst managers, we estimated a revised model that depicted planning sophistication affecting shared domain knowledge (see Fig. 2). This modification was consistent with the prior literature; more sophisticated strategic planning facilitates shared domain knowledge by providing a forum for business executives to learn about technology and IS executives to learn about the business [38], [66].

Results for the full samples in the two studies support the revised model. Table VIII provides the $R^{2} s$ and path coefficients for this model. In Study 1, the revised model explained 4\%, 10\%, and $10 \%$ of the variance in organizational performance, alignment, and shared domain knowledge, respectively. The corresponding figures in Study 2 were 16\%, 19\%, and 9\%, respectively. These $R^{2}$ values are generally comparable to the values reported in survey-based studies (e.g., [5], [24]), although studies involving laboratory experiments typically report higher $R^{2}$ values, potentially due to the greater control over variables not included in the model. The relatively low $R^{2}$ of $4 \%$ for organizational performance in Study 1 might reflect the fact that performance in business settings depends on numerous other factors, such as the competitors' and the firm's own actions in marketing, manufacturing, research and development, and other areas.

Most results were consistent across both studies. First, alignment affected organizational success, thus providing support for H6 regardless of industry or type of organization. Second, 
TABLE VIII

RESULTS FOR THE FULL SAMPLE FOR EACH STUDYa

\begin{tabular}{|c|c|c|c|c|c|c|}
\hline \multirow[b]{3}{*}{ Independent Variables } & \multicolumn{6}{|c|}{$\begin{array}{c}\text { Dependent Variables } \\
\text { (Standardized path coefficients) }\end{array}$} \\
\hline & \multicolumn{3}{|c|}{$\begin{array}{l}\text { Study 1: Business Firms } \\
\qquad(n=226)\end{array}$} & \multicolumn{3}{|c|}{$\begin{array}{l}\text { Study 2: Academic Institutions } \\
(\mathrm{n}=202)\end{array}$} \\
\hline & $\begin{array}{l}\text { Organizational } \\
\text { Success }\end{array}$ & Alignment & $\begin{array}{c}\text { Shared } \\
\text { Domain } \\
\text { Knowledge }\end{array}$ & $\begin{array}{l}\text { Organizational } \\
\text { Success }\end{array}$ & Alignment & $\begin{array}{c}\text { Shared } \\
\text { Domain } \\
\text { Knowledge }\end{array}$ \\
\hline D_PUB (1=public; $0=$ private) & & & & -.07 & .02 & .00 \\
\hline D_AUTO (1=auto-parts) & -.05 & -.03 & -.03 & & & \\
\hline D_BANK (1=banks) & .05 & .02 & .08 & & & \\
\hline D_INSU (1=insurance) & -.03 & -.06 & -.06 & & & \\
\hline D_PRO (1=Prospectors) & .11 & $-.17^{* *}$ & $.19^{* * *}$ & -.19 & $-.14^{*}$ & -.04 \\
\hline D_ANA (1=Analyzers) & .15 & -.10 & $.14^{*}$ & .11 & $.18^{\star \star}$ & .01 \\
\hline Alignment & $.18^{* * *}$ & & & $.16^{*}$ & & \\
\hline Shared Domain Knowledge & & $.17^{\star \star \star}$ & & & $.21^{* * *}$ & \\
\hline Planning Sophistication & & & $28^{* * *}$ & & & $.30^{* * *}$ \\
\hline Prior IS Success & & $.13^{*}$ & & & $.18^{\star *}$ & \\
\hline Organizational Size & -.04 & $.22^{* * *}$ & -.02 & $.31^{* * *}$ & .05 & .04 \\
\hline Environmental Uncertainty & & .03 & & & $.12^{*}$ & \\
\hline$R^{2}$ & .04 & .10 & .10 & .16 & .19 & .09 \\
\hline
\end{tabular}

${ }^{\text {a }}$ Dummy variables are set to zero in situations other than those specified above. Significance levels (two-tailed significance for dummy variables, one-tailed significance for hypothesized relationships) are as follows: ${ }^{*} p \leq 0.05$; ${ }^{* *} p \leq 0.01 ;$ and ${ }^{* * *} p \leq 0.005$.

shared domain knowledge and prior IS success consistently affected alignment, thus supporting $\mathrm{H} 1$ and $\mathrm{H} 3$, respectively, in the different settings examined. Finally, planning sophistication affected shared domain knowledge in both studies, supporting the modification to the original $\mathrm{H} 2$ in both these very different settings. In both settings, planning sophistication and shared domain knowledge were more important (substantive and significant) predictors than was prior IS success.

However, there were important differences across the two studies with respect to the effects of organizational size $(\mathrm{H} 4)$ and environmental uncertainty (H5) on alignment. Organizational size affected alignment significantly in business firms but not in academic institutions, whereas environmental uncertainty affected alignment significantly in academic institutions but not in business firms.

Differences Across Organizational Types and Business Strategies: The paper's second research objective was to explore the differences in the antecedents and performance implications of alignment across organizational types and across business strategies. Some differences across organizational types were detected by comparing results across the two studies. One such difference, in how uncertainty and organizational size affected alignment, was mentioned above. In business firms, organizational size affected alignment significantly as expected, but environmental uncertainty did not. By contrast, in academic institutions, environmental uncertainty affected alignment significantly as anticipated, but organizational size did not. Four dummy variables were included in the analysis to examine differences across various types of organizations in shared domain knowledge, alignment, or orga- nizational performance. These included three dummy variables used to examine the differences across industries in Study 1, and one dummy variable to examine differences between public and private institutions in Study 2. As Table IX indicates, no significant differences across different types of organizations were found in shared domain knowledge, alignment, or organizational performance.

Two other dummy variables were included in the analysis to examine the differences across Prospector, Analyzer, and Defender business strategies in both studies. As Table IX indicates, some significant differences existed across business strategies. First, Prospectors had lower alignment than Defenders and Analyzers in both studies. Second, Prospector and Analyzer business firms had greater shared domain knowledge than other business firms, although these differences were not seen in academic institutions. Finally, Analyzer academic institutions had greater alignment than the others, although this difference was not seen in business firms.

The analysis for each strategy type (see Table IX) provides further insights into the differences across the three business strategies. Alignment affected organizational success (H6) consistently, although Defender business firms were an exception. Shared domain knowledge affected alignment in business firms (H1), but only in academic institutions pursuing a Defender strategy. Planning sophistication consistently affected shared domain knowledge, with no exceptions (H2). Organizational size affected alignment in business firms but not in academic institutions, regardless of the business strategy (H4). Greater differences across strategies were seen with respect to the effects of prior IS success (H3) and environmental uncertainty 
TABLE IX

RESULTS FOR EACH STRATEGYa

\begin{tabular}{|c|c|c|c|c|c|c|c|c|c|}
\hline & & & \multicolumn{6}{|c|}{ Independent Variables } & \multirow[b]{2}{*}{$\mathrm{R}^{2}$} \\
\hline & & Dependent Variables & 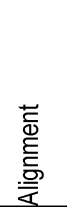 & 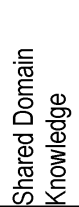 & 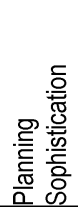 & 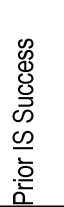 & 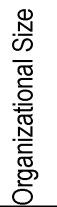 & 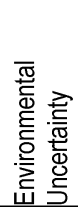 & \\
\hline \multirow{9}{*}{ 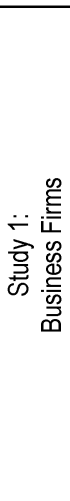 } & \multirow[t]{3}{*}{$\begin{array}{l}\text { Defenders } \\
(n=48)\end{array}$} & $\begin{array}{l}\text { Organizational } \\
\text { Success }\end{array}$ & .04 & & & & & & .001 \\
\hline & & Alignment & & $.25^{*}$ & & $.32^{*}$ & $.26^{*}$ & $.27^{*}$ & .220 \\
\hline & & $\begin{array}{l}\text { Shared domain } \\
\text { knowledge }\end{array}$ & & & $.32^{*}$ & & & & .102 \\
\hline & \multirow[t]{3}{*}{$\begin{array}{l}\text { Prospectors } \\
(n=78)\end{array}$} & $\begin{array}{l}\text { Organizational } \\
\text { Success }\end{array}$ & $.22^{*}$ & & & & & & .050 \\
\hline & & Alignment & & $.25^{*}$ & & .15 & $.18^{\#}$ & .06 & .128 \\
\hline & & $\begin{array}{l}\text { Shared domain } \\
\text { knowledge }\end{array}$ & & & $.40^{* \star \star}$ & & & & .158 \\
\hline & \multirow[t]{3}{*}{$\begin{array}{l}\text { Analyzers } \\
(n=100)\end{array}$} & $\begin{array}{l}\text { Organizational } \\
\text { Success }\end{array}$ & $.24^{* *}$ & & & & & & .058 \\
\hline & & Alignment & & $.16^{\#}$ & & .13 & $.19^{*}$ & .07 & .082 \\
\hline & & $\begin{array}{l}\text { Shared domain } \\
\text { knowledge }\end{array}$ & & & $.30^{\star \star *}$ & & & & .088 \\
\hline \multirow{9}{*}{ 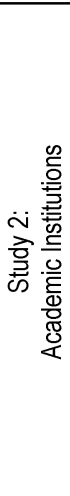 } & \multirow[t]{3}{*}{$\begin{array}{l}\text { Defenders } \\
(n=146)\end{array}$} & $\begin{array}{l}\text { Organizational } \\
\text { Success }\end{array}$ & $.16^{*}$ & & & & & & .027 \\
\hline & & Alignment & & $.15^{*}$ & & $.19^{* *}$ & .06 & .08 & .097 \\
\hline & & $\begin{array}{l}\text { Shared domain } \\
\text { knowledge }\end{array}$ & & & $.27^{\star \star *}$ & & & & .074 \\
\hline & \multirow[t]{3}{*}{$\begin{array}{l}\text { Prospectors } \\
(n=31)\end{array}$} & $\begin{array}{l}\text { Organizational } \\
\text { Success }\end{array}$ & $.35^{*}$ & & & & & & .125 \\
\hline & & Alignment & & .26 & & $.38^{*}$ & .15 & .01 & .366 \\
\hline & & $\begin{array}{l}\text { Shared domain } \\
\text { knowledge }\end{array}$ & & & $.35^{*}$ & & & & .251 \\
\hline & \multirow[t]{3}{*}{$\begin{array}{l}\text { Analyzers } \\
(n=25)\end{array}$} & $\begin{array}{l}\text { Organizational } \\
\text { Success }\end{array}$ & $.45^{*}$ & & & & & & .202 \\
\hline & & Alignment & & .15 & & .14 & .17 & $.37^{*}$ & .390 \\
\hline & & $\begin{array}{l}\text { Shared domain } \\
\text { knowledge }\end{array}$ & & & $.43^{*}$ & & & & .184 \\
\hline
\end{tabular}

${ }^{a}$ The table provides standardized path coefficients.

Significance levels (one-tailed) are as follows: \# $p \leq 0.10 ;{ }^{*} p \leq 0.05 ;{ }^{* *} p \leq 0.01$; ${ }^{* * *} p \leq 0.005$.

(H5) on alignment. Uncertainty affected alignment in Defender business firms and Analyzer academic institutions, but not in the other four groups of organizations. Prior IS success did not seem to affect alignment in Analyzers, but it did affect alignment in Defenders (business firms as well as academic institutions) and Prospector academic institutions (but not business firms). These findings suggest that for managers in firms in different industrial sectors, employing different strategies, the relative importance of alignment antecedents varies markedly.

\section{DISCUSSION}

\section{A. Summary of Findings}

This paper began with two broad research objectives: 1) empirically testing the theoretical model including the relationships of alignment with its antecedents and organizational performance and 2) examining differences across organizational types and business strategies in terms of the test results. This paper used empirical data from two prior studies on business firms [56] and academic institutions [57] to pursue these objectives. We now examine the findings related to these two objectives. Table X, which summarizes the empirical results for the full sample as well as for each business strategy within each study, is used to guide this discussion.

In pursuing the first research objective, we found the a priori theoretical model to receive considerable overall support. However, one modification was necessary in the effect of planning sophistication; Hypothesis 2 was not supported, and a modified effect (called "2 Revised" in Table X), proposing planning sophistication to affect shared knowledge, was supported. Thus, instead of directly affecting alignment, planning sophistication was found to indirectly affect alignment-through shared domain knowledge. The support for the revised model was consistent across the two studies, with five of the six paths in the model being supported in the full sample in each study. Four paths in the revised model were significant in both studies: 1) from sophistication of strategic planning to shared domain knowledge; 2) from shared domain knowledge to alignment; 3 ) from prior 
TABLE $X$

SUMMARY OF RESULTS ${ }^{\mathrm{a}}$

\begin{tabular}{|c|c|c|c|c|c|c|c|c|}
\hline \multirow[t]{2}{*}{ Hypotheses } & \multicolumn{4}{|c|}{ Study 1: Business Firms } & \multicolumn{4}{|c|}{ Study 2: Academic Institutions } \\
\hline & $\begin{array}{c}\text { Full } \\
\text { Sample }\end{array}$ & Defenders & Prospectors & Analyzers & $\begin{array}{c}\text { Full } \\
\text { Sample }\end{array}$ & Defenders & Prospectors & Analyzers \\
\hline $\begin{array}{l}\text { 1: Shared knowledge between business and } \\
\text { IS executives is positively related to } \\
\text { alignment. }\end{array}$ & Supported & Supported & Supported & $\begin{array}{l}\text { Moderately } \\
\text { supported }\end{array}$ & Supported & Supported & $\begin{array}{c}\text { Not } \\
\text { supported }\end{array}$ & $\begin{array}{c}\text { Not } \\
\text { supported }\end{array}$ \\
\hline $\begin{array}{l}\text { 2: Planning sophistication is positively } \\
\text { related to alignment. }\end{array}$ & $\begin{array}{c}\text { Not } \\
\text { supported }\end{array}$ & Not tested & Not tested & Not tested & $\begin{array}{c}\text { Not } \\
\text { supported }\end{array}$ & Not tested & Not tested & Not tested \\
\hline $\begin{array}{l}2 \text { Revised: Planning sophistication is } \\
\text { positively related to shared domain } \\
\text { knowledge. }\end{array}$ & Supported & Supported & Supported & Supported & Supported & Supported & Supported & Supported \\
\hline $\begin{array}{l}\text { 3: Prior IS success is positively related to } \\
\text { alignment. }\end{array}$ & Supported & Supported & $\begin{array}{c}\text { Not } \\
\text { supported }\end{array}$ & $\begin{array}{c}\text { Not } \\
\text { supported }\end{array}$ & Supported & Supported & Supported & $\begin{array}{c}\text { Not } \\
\text { supported }\end{array}$ \\
\hline $\begin{array}{l}\text { 4: Organizational size is positively related to } \\
\text { alignment. }\end{array}$ & Supported & Supported & $\begin{array}{l}\text { Moderately } \\
\text { supported }\end{array}$ & Supported & $\begin{array}{c}\text { Not } \\
\text { supported }\end{array}$ & $\begin{array}{c}\text { Not } \\
\text { supported }\end{array}$ & $\begin{array}{c}\text { Not } \\
\text { supported }\end{array}$ & $\begin{array}{c}\text { Not } \\
\text { supported }\end{array}$ \\
\hline $\begin{array}{l}\text { 5: Environmental uncertainty is positively } \\
\text { related to alignment. }\end{array}$ & $\begin{array}{c}\text { Not } \\
\text { supported }\end{array}$ & Supported & $\begin{array}{c}\text { Not } \\
\text { supported }\end{array}$ & $\begin{array}{c}\text { Not } \\
\text { supported }\end{array}$ & Supported & $\begin{array}{c}\text { Not } \\
\text { supported }\end{array}$ & $\begin{array}{c}\text { Not } \\
\text { supported }\end{array}$ & Supported \\
\hline $\begin{array}{l}\text { 6: Alignment is positively related to } \\
\text { organizational performance. }\end{array}$ & Supported & $\begin{array}{c}\text { Not } \\
\text { supported }\end{array}$ & Supported & Supported & Supported & Supported & Supported & Supported \\
\hline
\end{tabular}

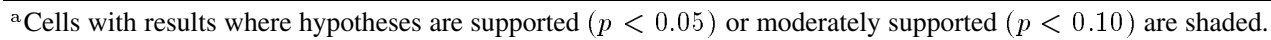

IS success to alignment; and 4) from alignment to organizational performance. Thus, there is consistent empirical support for the argument that planning sophistication promotes shared domain knowledge, which, along with prior IS success, facilitates alignment. Alignment, in turn, facilitates organizational performance.

In addition, the strongest paths existed between planning sophistication and shared knowledge. The next strongest paths were those between shared knowledge and alignment. The good news for organizations with less than stellar track records was that prior IS success, while influencing alignment, had less of an impact than shared knowledge. Managers seeking to improve shared business and IS knowledge can do so via their IS planning or business planning processes. Each of two other paths, from organizational size and environmental uncertainty to alignment, received partial support, being significant in one study but not in the other. Cumulatively, these findings highlight the greatest importance offactors directly related to IS management (i.e., shared knowledge and planning sophistication), followed by the credibility or the track record of the IS group (i.e., prior IS success), and then factors most remote to IS and IS management (i.e., organizational size and environmental uncertainty). These results are intuitively appealing, although not reported in prior empirical studies.

The second objective of this paper was to explore differences across organizational types and across business strategies in terms of alignment and its antecedents and performance implications. We examined these differences in three ways: 1) by examining the differences across business firms (Study 1) and academic institutions (Study 2) in terms of the results for the full sample (see Tables VIII and X); 2) by testing the model separately for Defenders, Prospectors, and Analyzers (see Tables IX and X); and 3) by using dummy variables (see Table VIII) to study differences across four industries (Study 1) and between public and private institutions (Study 2).
The first finding related to the effect of business strategy on the level of alignment. As may be seen in Table VIII, the dummy variable for Prospectors had a significant negative effect on alignment in both business firms, as well as academic institutions. Thus, alignment is more difficult to achieve in Prospectors as compared to both Defenders and Analyzers. This finding seems quite consistent with the more dynamic nature of Prospectors.

Another finding related to the second research objective is the difference between business firms and academic institutions in the effect of organizational size on alignment. For the full sample as well as for each strategy type, organizational size affects alignment significantly in business firms but not in academic institutions. Institutional theory provides a plausible explanation for this difference, as business firms and academic institutions operate within substantially different institutional environments [59]. Academic institutions vary in size (e.g., in student enrollment), but they frequently possess leaders with comparable experience and qualifications (e.g., most university presidents and provosts possess Ph.D. degrees), as well as similar organizational structures and processes. Due to this greater similarity in institutional contexts [62], larger size may not result in increased need for explicit mechanisms for alignment in academic institutions to the same extent. This finding is also consistent with the notion that large businesses have more organizational slack ${ }^{8}$ to invest in aligning business and IS strategies than their smaller counterparts. Our results suggest that managers in successful large business firms use the "slack" or resources available to focus more attention on identifying and implementing technologies that closely support business strategy.

Another emergent result concerns the difference between business firms and academic institutions in the effect of environ-

\footnotetext{
${ }^{8}$ Organizational slack refers to resources available to respond to changes or to invest in new projects [47].
} 
mental uncertainty on alignment. Across strategies, uncertainty affects alignment significantly in academic institutions but not in business firms (see Table VIII). However, the difference is less clear when examining this relationship for each strategy (see Table IX). Uncertainty seems to affect alignment for only one, and the least commonly used, strategy in academic institutions (Analyzers), as well as business firms (Defenders). Uncertainty does not influence alignment significantly in the other two strategies in each study. These mixed results have been documented in another recent study [4] and highlight the need for additional (e.g., longitudinal) research on the impact of environmental uncertainty on alignment in organizations pursuing different strategies. However, there is one clear finding related to environmental uncertainty from the current study: its effect on alignment is not supported for Prospectors, both in Study 1 and Study 2. This may reflect the greater difficulty in aligning business strategy and IS strategy, when both the environments and strategies are likely to be highly dynamic, as is the case with Prospectors in uncertain environments.

A fourth finding related to the second research objective is the difference between Defenders and Analyzers in the effect of prior IS success on alignment. Whereas prior IS success significantly affects alignment in Defenders in business firms, as well as academic institutions, it does not significantly affect alignment in Analyzers in either business firms or academic institutions. These differences may be related to the greater stability of Defenders in both business and IS domains, and the increased attention given to past performance. This might lead to the expectation of Prospectors which, like Analyzers, encounter greater changes, also having no significant association between prior IS success and alignment; the results are consistent with this expectation in business firms but surprisingly not in academic institutions.

Finally, a couple of inconsistencies with otherwise strong results should be noted. One such inconsistency relates to Hypothesis 6. Alignment has a positive effect on organizational performance in both full samples as well as in five of the six individual business strategy situations. The only exception is Defender business firms, for which this hypothesis is not supported. The second inconsistency relates to Hypothesis 1 . Shared knowledge has a positive effect on alignment in both full samples, as well as in four of the six individual business strategy situations. The two exceptions, for which Hypothesis 1 is not supported, are both within academic institutions-Prospectors and Analyzers. These nonfindings remind us of the importance of strategy and industry, and need to be further investigated in future alignment research.

\section{B. Practical Implications}

At the most basic level, our results provide additional empirical support for the popular argument that strategic IS alignment improves organizational performance. The results suggest that the effects of alignment on organizational performance, as well as the factors influencing alignment, vary across business strategies and across different types of organizations (e.g., business firms and academic institutions). Consistent with this perspective, the influence of managing environmental uncertainty, organizational size, and prior success varies across organizational types and across business strategies [46]. The effects of alignment on organizational performance also vary depending on business strategy. Specifically, alignment enhanced performance across industrial sectors in Prospectors and Analyzers, suggesting that these types of organizations should pay close attention to how they use IS to support their business strategies. However, in Defenders, alignment's effects differed across business firms and universities. These results suggest that the importance of alignment as well as the mechanisms used to attain alignment depend on the organization's business strategy and industry. This is an important observation for practitioners. Not all firms are equally well served by allocating scarce resources to improve IS alignment. Among business firms, it would appear that Prospectors and Analyzers have more to gain from aligning business and IS strategies.

The paper also illuminates the strong influence of a process variable, strategic planning, on the development of shared knowledge and, consequently, on alignment. Reich and Benbasat [54] assert that the level of shared knowledge in a firm affects communication among top managers and linkages among planning processes. Vitale et al. [67] also observe that processes that enhance managers' shared knowledge contribute to alignment between IS and firm strategy. While we do not explicitly examine processes within individual firms, our findings support the view that strategic planning processes influence shared knowledge between IS executives and top managers, and this in turn has a substantive and significant impact on alignment. Practitioners are more likely to reap important alignment and performance rewards when they utilize sophisticated planning approaches to enhance shared business and IS knowledge.

In addition, the paper supports the view that past implementation success influences alignment between IS and business strategy, an argument that has historically suffered from a lack of empirical attention. This is true in general, and also when findings are examined by strategy type and industrial sector. By definition, Defenders are more reluctant to adopt new technologies than Prospectors or Analyzers. In this study, past success was a significant predictor of alignment for Defenders in both business firms and universities. This finding implies a possible "snowball" effect on Defenders' alignment between business and IS strategies. If they have had prior IS success, Defenders may be more inclined to utilize IT to protect their market position. For practitioners, this finding reinforces the importance of establishing and maintaining a strong IS department track record, especially in Defender firms, where the past may be more likely to be considered as a predictor of the future. However, the effect of prior IS success on alignment is not found in Analyzers. 
Thus, our findings demonstrate that at least in Defenders, past successes and failures expand or limit what can realistically be expected with respect to current IS alignment and performance.

Finally, our results suggest that managers in most business firms experiencing high environmental uncertainty will gain little by focusing on IS alignment. They can use their resources in more fruitful ways. However, managers in academic institutions pursuing an Analyzer strategy, and in business firms pursuing a Defender strategy, can more readily improve their alignment in these circumstances. The converse is true with respect to organizational size. Managers in large business firms should invest slack resources on explicit alignment mechanisms, but this cannot be suggested to managers in large academic institutions. These findings suggest the importance of participation in professional peer communities. While it is important for IS managers in business firms and academic institutions to be educated similarly (e.g., via periodicals and conferences), clearly there are industry-specific phenomena with which they must contend. Certain IS management issues and solutions are not common across settings.

\section{Implications for Future Research}

This paper provides insights into why prior research may have reported diverse, and sometimes conflicting, findings regarding antecedents to IS and business strategy alignment. Although past industry-specific analyses have been helpful, much previous research has ignored strategic orientation, thereby masking the effects various factors have on alignment in organizations pursuing different business strategies. This suggests that by controlling for differences in strategic orientations in future research, we may better link antecedents to alignment, and consequently alignment to performance.

This study has revealed several areas where studies on specific business strategies might be valuable. For example, future research on Defender business firms is needed to help understand why, contrary to the widespread expectations regarding a positive association between alignment and organizational performance, these constructs are not positively associated in this context. Similarly, further research is needed to better understand why prior IS success affects alignment in Defenders but not in Analyzers.

Some factors that limit the general applicability of our study's findings also guide our suggestions for future research. First, our research was limited to five industries (banking, insurance, pharmaceuticals, auto parts, and higher education), thereby potentially limiting the generalizability of its results beyond these industries. A related limitation is that this paper relies on a relatively simple typology to classify firms possessing "pure" strategies, whereas firms often evidence hybrid or mixed strategies. In the future, other industries should be examined. In addition, more sophisticated analyses should evaluate the relationships among hybrid strategies, alignment, and organizational performance.
This paper uses cross-sectional analysis to evaluate antecedents and performance implications of alignment. It would be useful to conduct longitudinal research on alignment antecedents and consequences. Such future research would provide valuable insights into the influence of the dynamic interaction of antecedent factors and alignment on organizational performance over time.

Finally, this study only briefly addresses processes that lead to shared knowledge. Limited quantitative [67] and qualitative [55] research has explored processes that serve as antecedents to alignment. A logical extension of the alignment research stream would be to engage in quantitative and qualitative studies that link features of strategic planning processes to shared knowledge and IS alignment. The relationships among these processes and factors have been found to be strong, and merit in-depth examination.

\section{CONCLUSION}

This paper has used data on business firms and academic institutions to examine antecedents and effects of alignment between business and IS strategies. It has made two important contributions. First, it has developed and empirically tested a comprehensive model including several factors affecting alignment as well as the effects of alignment on organizational performance. The empirical results provide good overall support for the expected effects on alignment, with the aspect most directly related to IS management (i.e., shared knowledge) having the most consistent effect on alignment, followed by the credibility or the track record of the IS group (i.e., prior IS success), and then factors most remote to IS and IS management (i.e., organizational size and environmental uncertainty). The results also demonstrate, for most firms, the positive effect of alignment on organizational performance.

Second, the paper empirically examines how the relationships among antecedents, alignment, and organizational performance vary by industry, type of firm, and organizational strategy. Our findings indicate that while most types of organizations benefit when managers invest resources to promote IS alignment, this does not appear to be the case for Defender business firms. Moreover, differences are observed across the three strategies as well as across business firms and academic institutions in terms of the relative importance of factors affecting alignment between business strategy and IS strategy. There is no one "standard" method for improving alignment.

Thus, our results help to explain why previous IS alignment studies have reported differing, even seemingly contradictory, findings. The research on alignment is in no way complete. The current study highlights the need for future research on industry-specific and strategy-specific IS alignment and performance challenges. 


\section{APPENDIX A \\ MEASURES AND THEIR PSYCHOMETRIC PROPERTIES}

APPENDIX A-1: STUDY 1

FACTOR ANALYSIS OF MEASURES OF BUSINESS STRATEGy ATtRIBUTES

\begin{tabular}{|c|c|}
\hline \multicolumn{2}{|c|}{ DEF: Factor 1 for Business Strategy -- Defensiveness (Cronbach's alpha $=.72$, mean $=3.76$, s.d. $=.79$ ) } \\
\hline DEF1 & We develop strong relationships with our suppliers. \\
\hline DEF2 & We develop strong relationships with our customers. \\
\hline DEF3 & We optimize coordination across our departments and/or product lines. \\
\hline DEF4 & There is a constant drive to improve operating efficiency. \\
\hline \multicolumn{2}{|c|}{ ANALY: Factor 2 for Business Strategy - Analysis (Cronbach's alpha $=.71$, mean $=3.04$, s.d. $=.79$ ) } \\
\hline ANALY1 & We tend to be number-oriented and analytical in our operations. \\
\hline ANALY2 & We require detailed, factual information to support our day-to-day decision making. \\
\hline ANALY3 & We develop comprehensive analyses of each business opportunity or challenge we face. \\
\hline \multicolumn{2}{|c|}{ RSKAVR: Factor 3 for Business Strategy - Risk Aversion (Cronbach's alpha $=.74$, mean $=4.04$, s.d. $=.64$ ) } \\
\hline RSKAVR1 & Our business decisions generally follow 'tried and true' paths. \\
\hline RSKAVR2 & We adopt a rather conservative view when making major decisions. \\
\hline RSKAVR3 & In general, our mode of operations is less risky than that of our competitors. \\
\hline \multicolumn{2}{|c|}{ PROACT: Factor 4 for Business Strategy - Proactiveness (Cronbach's alpha $=.60$, mean $=2.54$, s.d. $=.84$ ) } \\
\hline PROACT1 & $\begin{array}{l}\text { We generally increase capacity (i.e., prepare to handle a greater volume of business) before our } \\
\text { competitors do the same. }\end{array}$ \\
\hline PROACT2 & We are usually the first ones to introduce various products and/or services in the market. \\
\hline PROACT3 & We adopt innovations early. \\
\hline \multicolumn{2}{|c|}{ FUT: Factor 5 for Business Strategy $=$ Futurity (Cronbach's alpha $=.73$, mean $=3.22$, s.d. $=.99$ ) } \\
\hline FUT1 & $\begin{array}{l}\text { The performance measures reviewed by the senior management team emphasize our long-term } \\
\text { business effectiveness. }\end{array}$ \\
\hline FUT2 & Our criteria for budget allocations generally reflect long-term considerations. \\
\hline \multicolumn{2}{|c|}{ AGGR: Factor 6 for Business Strategy -- Aggressiveness (Cronbach's alpha $=.67$, mean $=3.42$, s.d. $=.78$ ) } \\
\hline AGGR1 & We sacrifice current profitability to gain market share. \\
\hline AGGR2 & Gaining market share is more important than cash flow. \\
\hline AGGR3 & We frequently use price-cutting to increase our market share. \\
\hline
\end{tabular}

\begin{tabular}{|l|c|c|c|c|c|c|}
\hline \multicolumn{7}{|c|}{ Rotated Factor Matrix } \\
\hline & Factor 1 & Factor 2 & Factor 3 & Factor 4 & Factor 5 & Factor 6 \\
\hline Eigenvalues & 3.74 & 2.41 & 1.67 & 1.54 & 1.19 & 1.10 \\
\hline \% variance & 20.8 & 13.4 & 9.3 & 8.5 & 6.6 & 6.1 \\
\hline DEF1 & .83 & .05 & -.11 & .02 & .04 & .06 \\
DEF2 & .76 & .15 & .15 & .12 & .05 & .04 \\
DEF3 & .64 & .22 & -.02 & .10 & .31 & -.11 \\
DEF4 & .52 & .37 & -.05 & .29 & .01 & -.10 \\
\hline ANALY1 & .04 & .81 & .16 & .05 & .08 & .01 \\
ANALY3 & .27 & .76 & .01 & .14 & -.00 & -.07 \\
ANALY2 & .14 & .74 & .00 & -.02 & .09 & .01 \\
\hline RSKAVR2 & -.15 & .12 & .81 & -.13 & .19 & -.07 \\
RSKAVR1 & -.04 & .06 & .79 & -.06 & -.16 & .08 \\
RSKAVR3 & .15 & -.013 & .66 & -.06 & .07 & -.12 \\
\hline PROACT1 & .04 & .08 & .08 & .81 & .07 & .05 \\
PROACT2 & .18 & .05 & -.16 & .76 & -.02 & .12 \\
PROACT3 & .15 & .05 & -.36 & .67 & .29 & -.01 \\
\hline FUT1 & .05 & .03 & -.02 & .08 & .87 & .08 \\
FUT2 & .20 & .13 & .09 & .11 & .81 & -.01 \\
\hline \multicolumn{7}{|l|}{} \\
\hline AGGR1 & .11 & -.02 & .01 & .07 & .17 & .80 \\
AGGR2 & -.07 & -.12 & .01 & .11 & .08 & .72 \\
AGGR3 & -.07 & .12 & -.16 & -.04 & -.26 & .68 \\
\hline
\end{tabular}


APPENDIX A-1: STUDY 1

FACtor ANALYSIS OF MEASURES OF IS StRATEGy ATtRIbUTES

\begin{tabular}{|c|c|}
\hline \multicolumn{2}{|c|}{ ISOPSUP: Factor 1 for IS Strategy -- Operational Support Systems (Cronbach's alpha $=.88$, mean = 3.61, s.d. $=.71$ ) } \\
\hline ISOPSUP1 & Our IS improve the efficiency of our day-to-day business operations. \\
\hline ISOPSUP2 & $\begin{array}{l}\text { Our IS support effective coordination across functions (e.g., marketing, manufacturing) and } \\
\text { product lines. }\end{array}$ \\
\hline ISOPSUP3 & $\begin{array}{l}\text { Our IS provide us with the facts and figures we need to support our day-to-day decision } \\
\text { making. }\end{array}$ \\
\hline ISOPSUP4 & Our IS enable us to develop detailed analyses of our present business situation. \\
\hline ISOPSUP5 & Our IS provide sufficiently detailed information to support prudent decision making. \\
\hline ISOPSUP6 & Our IS support detailed analyses of major business decisions. \\
\hline \multicolumn{2}{|c|}{ ISIOR: Factor 2 for IS Strategy - Interorganizational Systems (Cronbach's alpha $=.79$, mean $=3.20$, s.d. $=.78$ ) } \\
\hline ISIOR1 & Our IS enable us to develop stronger links with suppliers. \\
\hline ISIOR2 & Our IS enhance our ability to negotiate with our suppliers. \\
\hline ISIOR3 & Our IS enhance our ability to negotiate with our customers. \\
\hline ISIOR4 & Our IS enable us to develop stronger links with customers. \\
\hline \multicolumn{2}{|c|}{ ISMARK: Factor 3 for IS Strategy -- Market Information Systems (Cronbach's alpha = .67, mean = 3.24, s.d. = .78) } \\
\hline ISMARK1 & Our IS assist us in setting our prices relative to the competition. \\
\hline ISMARK2 & Our IS help us introduce new products and/or services in our markets. \\
\hline ISMARK3 & Our IS help us monitor changes in our market share. \\
\hline ISMARK4 & Our IS permit us to rapidly adjust our prices. \\
\hline \multicolumn{2}{|c|}{ ISFUT: Factor 4 for IS Strategy -- Strategic Decision Support Systems (Cronbach's alpha $=.70$, mean $=2.92$, s.d. $=.92$ ) } \\
\hline ISFUT1 & Our IS facilitate strategic business planning. \\
\hline ISFUT2 & Our IS help us model possible future outcomes of alternative courses of action. \\
\hline ISFUT3 & Our IS are used to forecast key indicators of business performance. \\
\hline
\end{tabular}

\begin{tabular}{|l|c|c|c|c|}
\hline \multicolumn{5}{|c|}{ Rotated Factor Matrix } \\
\hline & Factor 1 & Factor 2 & Factor 3 & Factor 4 \\
\hline Eigenvalues & 6.85 & 1.37 & 1.14 & 0.97 \\
\hline \% variance & 40.3 & 8.1 & 6.7 & 5.7 \\
\hline ISOPSUP4 & .77 & .22 & .18 & .21 \\
ISOPSUP3 & .75 & .29 & .19 & .15 \\
ISOPSUP6 & .71 & .11 & .17 & .32 \\
ISOPSUP5 & .70 & .14 & .31 & .20 \\
ISOPSUP2 & .69 & .22 & .24 & .08 \\
ISOPSUP1 & .60 & .37 & .13 & .05 \\
\hline ISIOR1 & .23 & .74 & .05 & .17 \\
ISIOR3 & .13 & .70 & .19 & .27 \\
ISIOR2 & .27 & .69 & .01 & .25 \\
ISIOR4 & .27 & .63 & .36 & .11 \\
\hline ISMARK1 & .19 &. .04 & .80 & .17 \\
ISMARK2 & .17 & .37 & .64 & .06 \\
ISMARK3 & .36 & .08 & .49 & .11 \\
ISMARK4 & .29 & .39 & .47 & -.06 \\
\hline ISFUT1 & .18 & .22 & .05 & .79 \\
ISFUT2 & .10 & .17 & .21 & .77 \\
ISFUT3 & .37 & .22 & .01 & .58 \\
\hline
\end{tabular}


APPENDIX A-2: STUDY 2

FACTOR ANALYSIS OF MEASURES OF BUSINESS STRATEGy ATTRIBUTES

\begin{tabular}{|c|c|}
\hline \multicolumn{2}{|c|}{ RISK - Factor 1 - Risk Averseness (Cronbach's alpha $=.87$, mean $=5.25$, s.d. $=1.02$ ) } \\
\hline RSKAVR1 & Administration responsiveness to students' suggestions and grievances. \\
\hline RSKAVR2 & Administration responsiveness to faculty suggestions and grievances. \\
\hline RSKAVR3 & Administration responsiveness to staff suggestions and grievances. \\
\hline \multicolumn{2}{|c|}{ AGGR - Factor $2-$ Aggressiveness (Cronbach's alpha $=.81$, mean $=4.93$, s.d. $=1.12$ ) } \\
\hline AGGR1 & Financial and other support from industry. \\
\hline AGGR2 & Financial and other support from Alumni. \\
\hline AGGR3 & Financial and other support from federal, state, and local governments. \\
\hline \multicolumn{2}{|c|}{ PROACT - Factor $3-$ Proactiveness (Cronbach's alpha $=.79$, mean $=5.23$, s.d. $=1.18$ ) } \\
\hline PROACT1 & Innovative teaching approaches. \\
\hline PROACT2 & Course integration into the curricula. \\
\hline PROACT3 & An up-to-date curriculum. \\
\hline PROACT4 & Formal networks for course and instructor evaluation. \\
\hline \multicolumn{2}{|c|}{ ANALY- Factor $4-$ Analysis (Cronbach's alpha $=.71$, mean $=5.05$, s.d. $=1.06$ ) } \\
\hline ANALY1 & A curriculum which meets employers needs. \\
\hline ANALY2 & A curriculum which meets students needs. \\
\hline ANALY3 & Student placement (for jobs, internships, etc.). \\
\hline \multicolumn{2}{|c|}{ DEF - Factor 5 - Defensiveness (Cronbach's alpha $=.78$, mean $=4.98$, s.d. $=1.12$ ) } \\
\hline DEF1 & $\begin{array}{l}\text { A 'mentor' relationship between students and advisor/faculty (versus a scheduling/course } \\
\text { selection focus). }\end{array}$ \\
\hline DEF2 & Friendly relationships between students and faculty. \\
\hline DEF3 & Low student/faculty ratio. \\
\hline \multicolumn{2}{|c|}{ FUT - Factor 6 - Futurity (Cronbach's alpha $=.76$, mean $=5.48$, s.d. $=1.15$ ) } \\
\hline FUT1 & Provision of faculty salaries/grants/raises. \\
\hline FUT2 & Ability to attract and keep quality faculty. \\
\hline FUT3 & Other faculty support (assistants, travel, physical space). \\
\hline
\end{tabular}

\begin{tabular}{|c|c|c|c|c|c|c|}
\hline \multicolumn{7}{|c|}{ Rotated Factor Matrix } \\
\hline & 1 & 2 & 3 & 4 & 5 & 6 \\
\hline Eigenvalues & 7.21 & 2.45 & 1.52 & 1.35 & 1.09 & 0.94 \\
\hline \% Variance & 35.25 & 11.67 & 7.25 & 6.58 & 5.05 & 4.46 \\
\hline RSKAVR1 & $\mathbf{0 . 8 1}$ & 0.06 & 0.12 & 0.21 & 0.13 & 0.08 \\
\hline RSKAVR2 & $\mathbf{0 . 8 0}$ & 0.12 & 0.18 & 0.08 & 0.16 & 0.27 \\
\hline RSKAVR3 & $\mathbf{0 . 7 9}$ & 0.15 & 0.27 & 0.08 & 0.22 & 0.08 \\
\hline AGGR1 & 0.19 & $\mathbf{0 . 8 3}$ & 0.04 & 0.13 & 0.15 & 0.10 \\
\hline AGGR2 & 0.26 & $\mathbf{0 . 7 5}$ & -0.03 & 0.24 & 0.25 & 0.15 \\
\hline AGGR3 & -0.04 & $\mathbf{0 . 7 4}$ & 0.23 & 0.01 & -0.03 & 0.18 \\
\hline PROACT1 & 0.10 & 0.32 & $\mathbf{0 . 7 1}$ & 0.08 & 0.27 & 0.00 \\
\hline PROACT2 & 0.30 & 0.16 & $\mathbf{0 . 6 9}$ & 0.23 & 0.11 & 0.11 \\
\hline PROACT3 & 0.25 & 0.09 & $\mathbf{0 . 6 4}$ & 0.38 & 0.09 & 0.17 \\
\hline PROACT4 & 0.23 & -0.11 & $\mathbf{0 . 6 0}$ & 0.22 & 0.22 & 0.28 \\
\hline ANALY1 & -0.04 & -0.08 & 0.20 & $\mathbf{0 . 8 3}$ & 0.06 & -0.02 \\
\hline ANALY2 & 0.16 & 0.20 & 0.24 & $\mathbf{0 . 6 6}$ & -0.02 & -0.03 \\
\hline ANALY3 & 0.19 & 0.06 & 0.02 & $\mathbf{0 . 6 6}$ & 0.37 & 0.17 \\
\hline DEF1 & 0.08 & 0.14 & 0.23 & 0.09 & $\mathbf{0 . 8 3}$ & -0.01 \\
\hline DEF2 & 0.22 & -0.03 & 0.12 & 0.22 & $\mathbf{0 . 7 9}$ & 0.07 \\
\hline DEF3 & 0.19 & 0.12 & 0.12 & 0.04 & $\mathbf{0 . 6 7}$ & 0.14 \\
\hline FUT1 & 0.13 & 0.34 & 0.02 & 0.21 & 0.07 & $\mathbf{0 . 7 8}$ \\
\hline FUT2 & 0.41 & 0.10 & 0.20 & -0.10 & 0.07 & $\mathbf{0 . 7 0}$ \\
\hline FUT3 & 0.10 & 0.41 & 0.28 & 0.08 & 0.23 & $\mathbf{0 . 6 1}$ \\
\hline
\end{tabular}


APPENDIX A-2: STUDY 2

FACTOR ANALYSIS OF MEASURES OF IS STRATEGY ATTRIBUTES ${ }^{\mathrm{a}}$

Factor 1 for IS Strategy - Operational Support Systems (Cronbach's alpha $=.81$, mean $=5.44$, s.d. $=1.27$ )

ISOPSUP1 Computer facilities for student projects.

ISOPSUP2 Computer labs for student instruction.

ISOPSUP3 Advanced computer facilities.

Factor 2 for IS Strategy ${ }^{b}$ Interorganizational Communication (Cronbach's alpha $=.76$, mean $=2.99$, s.d. $=1.66$ )

ISIOR1 E-mail services between students

ISIOR2 $\quad$ E-mail services for submitting and evaluating student work.

ISIOR3 E-mail for administrative communiques.

Factor 3 for IS Strategy - Marketing Information Systems (Cronbach's alpha $=.74$, mean $=3.66$, s.d. $=1.07$ )

ISMARK1 Introducing new courses and programs.

ISMARK2 Improving teaching approaches.

ISMARK3 Computer-aided curriculum design.

Rotated Factor Matrix

\begin{tabular}{|c|c|c|c|}
\hline & 1 & 2 & 3 \\
\hline Eigenvalues & 3.59 & 1.68 & 1.22 \\
\hline \% Variance & $39.89 \%$ & $18.68 \%$ & $13.64 \%$ \\
\hline ISOPSUP1 & 0.89 & 0.14 & 0.15 \\
ISOPSUP2 & 0.85 & 0.00 & 0.22 \\
ISOPSUP3 & 0.76 & 0.13 & 0.21 \\
\hline ISIOR1 & 0.19 & 0.90 & 0.00 \\
ISIOR2 & 0.19 & 0.90 & 0.11 \\
ISIOR3 & -0.11 & $\mathbf{0 . 6 4}$ & 0.31 \\
\hline ISMARK1 & 0.14 & 0.17 & 0.83 \\
ISMARK2 & 0.26 & 0.06 & $\mathbf{0 . 7 9}$ \\
ISMARK3 & 0.19 & 0.12 & $\mathbf{0 . 7 3}$ \\
\hline
\end{tabular}

a In Study 2, we lacked the items to measure strategic dimensions of IT (Factor 4, ISFUT, in Study 1). However, since this variable is coded as one for each strategy type, and thus does not change across the three strategies, we were able to proceed with the analysis.

b Although not used to communicate across organizations, these items measure how academic institutions may use information systems to foster communication with and between their stakeholders. For example, e-mail may be used to share information on new courses and services to independent consumers (i.e., students) and purchase goods from relatively autonomous suppliers (i.e., faculty). Although focused on coordination and production activities within academic institutions, these items thus capture applications of information systems similar to firms' use of interorganizational systems in broader markets. Because of the conceptual similarity, we chose to retain the 'interorganizational systems' label when reporting Study 2 results.

APPENDIX A-3

ITEMS USED IN THE RESEARCH MODEL

Organizational Success:

Study 1 These items were measured by comparing the company to its competitors, with scale ranging from $1=$ much worse than the competition to 5 $=$ much better than the competition. The items were collapsed into a single measure of performance, thus avoiding measurement error due to multidimensionality among indicators of a latent construct.

OSUC1 Reputation among major customer segments.

OSUC2 Frequency of new product or service introduction.

OSUC3 Return on investment.

OSUC4 Net profits.
OSUC5 Technological developments and/or other innovations in business operations.

OSUC6 Product quality.

OSUC7 Market share gains.

OSUC8 Revenue growth.

Study 2 Organizational success was computed as the mean of four secondary measures.

OSUC1 Student demand for the institution's services, computed as the ratio of the number of students applying for admission in 1989 to the number of students admitted that year.

OSUC2 Quality of students admitted, computed as the mean of the average Verbal and Mathematics SAT scores.

OSUC3 Quality of programs, computed as the mean of the Gourman rating of the institution's undergraduate and graduate programs. 
OSUC4 Prestige, as indicated by Barron's rating of the university.

Each of these four measures was converted to seven-point scales by computing their standardized scores and using cutoff points obtained by dividing the area under the normal curve into seven equal parts. The mean of the resulting seven-point scores was used to measure performance.

Shared Domain Knowledge: Shared domain knowledge was assessed using two items, assessing how informed IS managers were on the organization's long-term plans and how informed top management was on information technology.

Study 1

SDK1 IS managers are kept informed about key business initiatives and plans.

SDK2 Top management is involved in information technology developments.

Study 2

SDK1 How informed is the institution's top management about information technology.

SDK2 How informed are your information system managers about the institution's long-term plans.

Prior IS Success: Prior IS success was measured using three items.

Study 1

PRIOR1 IS managers are kept informed about key business initiatives and plans.

PRIOR2 Improved effectiveness improved effectiveness of management decision-making due to information systems.

PRIOR3 Introduction of new products and services based on advances in information technology.

Study 2

PRIOR1 Increase the efficiency of internal operations.

PRIOR2 Reduce administrative costs.

PRIOR3 Introduce new courses and programs.

Planning Sophistication: Planning sophistication was measured using three items.

Study 1 Presence of strategic planning processes was measured using three items.

SOPH1 Systems for strategic planning.

SOPH2 We carry out long-term research to provide us with a future competitive edge.

SOPH3 We optimize coordination among our functions (e.g., finance and marketing).

Study 2 Respondents were asked to evaluate the degree to which the firm relied on the following planning processes.

SOPH1 Planning for future operating policies (i.e., strategic planning).

SOPH2 Investment in long term projects (e.g., buildings, technical infrastructure).

SOPH3 Interacademic committees set up to promote on-going decision-making among units.
Environmental Uncertainty:

Study 1 Managers evaluated the influence of the following external conditions.

UNC1 Customer preferences and demand patterns.

UNC2 Competitor moves (pricing, product offerings, etc.).

UNC3 Regulatory or legislative influence.

Study 2 Administrators reported the influence of.

UNC1 Changing demand for various courses and programs.

UNC2 Innovations by similar institutions.

UNC3 Government actions and interference.

Organizational Size:

Study 1 To be consistent with Sabherwal and Chan (2001) the mean of these items was used in our data analysis. Both the size measures were viewed in a country-relative fashion. The values were standardized separately for Canadian and U.S. firms before recombining the two sets for further analysis.

SIZE1 Annual revenues.

SIZE2 Number of Employees.

Study 2

SIZE1 Total student enrollment at the university.

\section{APPENDIX B}

SUMMARY OF THE ANALYTICAL APPROACH

Step 1) Normalization.

- Computed normalized score for each research variable.

- Computed these normalized scores separately for each industry (four industries in Study 1 and all academic institutions in Study 2).

Step 2) Classification into Defenders, Prospectors, and Analyzers.

a) Identified the ideal business strategy types for organizations in Study 1 and Study 2.

- This was done based on theoretical profiles of business strategy attributes identified in Sabherwal and Chan [45].

- Ideal values of normalized scores were set to 1 , $0,-1$ for high, medium, and low, respectively.

b) Computed distances of each organization's profile of business strategy attributes from the ideal business strategy profiles for Defenders, Prospectors, and Analyzers [36].

- Euclidian distances were computed using normalized values of business strategy attributes.

c) Classified each company into Defenders, Prospectors, and Analyzers.

- This was done based on distances computed in Step $2 b$.

- Each company classified into the business strategy from whose ideal profile its profile of business strategy attributes was least distant. 
Step 3) Computation of alignment.

a) Identified the ideal profile of IS strategy attributes for each business strategy type.

- This was done based on theoretical profiles of IS strategy attributes for Defenders, Analyzers, and Prospectors, as developed by Sabherwal and Chan [45].

- Ideal values of normalized scores set to $1,0,-1$ for high, medium, and low, respectively.

b) Computed the Euclidian distance of each organization's profile of IS strategy attributes from the profile of IS strategy attributes for the business strategy type to which it belongs (i.e., the business strategy type in which it was classified in Step 2).

c) Computed alignment as one minus the distance computed in Step 3b.

Step 4) Test of the research hypotheses using partial least squares.

a) Tested hypotheses separately for each study.

b) Tested hypotheses separately for each business strategy type (Defenders, Prospectors, and Analyzers) within each study.

\section{REFERENCES}

[1] C. P. Armstrong and V. Sambamurthy, "Information technology assimilation in firms: The influence of senior leadership on IT infrastructures," Inf. Syst. Res., vol. 10, no. 4, pp. 304-327, 1999.

[2] D. Barclay, C. Higgins, and R. Thompson, "The partial least squares (PLS) approach to causal modeling: Personal computer adoption and use as an illustration," Technol. Studies, vol. 2, no. 2, pp. 285-309, 1995.

[3] G. Bassellier, B. H. Reich, and I. Benbasat, "Information technology competence of business managers: A definition and research model," $J$. Manage. Inf. Syst., vol. 17, no. 4, pp. 159-182, 2001.

[4] F. Bergeron, L. Raymond, and S. Rivard, "Fit in strategic information technology management research: An empirical comparison of perspectives," Omega, vol. 29, pp. 125-142, 2001.

[5] J. Birkinshaw, A. Morrison, and J. Hulland, "Structural and competitive determinants of a global integration strategy," Strategic Manage. J., vol. 16, no. 8, pp. 637-655, 1995.

[6] K. A. Bollen, Structural Equations with Latent Variables. New York: Wiley, 1989.

[7] A. C. Boynton and R. W. Zmud, "Information technology planning in the 1990s: Directions for practice and research," MIS Quart., vol. 11, no. 1, pp. 59-71, Mar. 1987.

[8] C. V. Brown and S. L. Magill, "Alignment of the IS functions with the enterprise: toward a model of antecedents," MIS Quart., vol. 18, no. 4, pp. 371-403, 1994.

[9] J. M. Burn and C. A. Szeto, "Comparison of the views of business and IT management on success factors for strategic alignment," Inf. Manage., vol. 37, no. 4, pp. 197-216, 2000.

[10] T. A. Byrd, V. Sambamurthy, and R. Zmud, "An examination of IT planning in a large, diversified public organization," Decision Sci., vol. 26, no. 1, pp. 49-74, 1995.

[11] Y. E. Chan, S. L. Huff, D. W. Barclay, and D. G. Copeland, "Business strategy orientation, information systems orientation and strategic alignment," Inf. Syst. Res., vol. 8, no. 2, pp. 125-150, 1997.

[12] W. W. Chin, "Issues and opinions on structural equation modeling," MIS Quart., vol. 22, no. 1, pp. vii-xvi, Mar. 1998.

[13] - "The partial least squares approach to structural equation modeling," in Modern Methods for Business Research, G. A. Marcoulides, Ed. Mahway, NJ: Lawrence Erlbaum, 1998, pp. 295-336.

[14] W. W. Chin and T. Frye, PLS Graph, 1996.

[15] W. W Chin and P. A. Todd, "On the use, usefulness, and ease of use of structural equation modeling in MIS research: A note of caution," MIS Quart., vol. 19, no. 2, pp. 237-246, 1995.
[16] P. Cragg, M. King, and H. Hussin, "IT alignment and firm performance in small manufacturing firms," J. Strategic Inf. Syst., vol. 11, pp. 109-132, 2002.

[17] R. L. Daft and R. H. Lengel, "Organizational information requirements, media richness and structural design," Manage. Sci., vol. 32, no. 3, pp. 554-571, 1986.

[18] J. de Leede, J. C. Looise, and B. C. M. Alders, "Innovation, improvement and operations: An exploration of the management of alignment," Int. J. Technol. Manage., vol. 23, no. 4, pp. 353-368, 2002.

[19] J. Delery and D. H. Doty, "Modes of theorizing in strategic human resource management: Tests of universalistic, contingency, and configurational performance predictors," Acad. Manage. J., vol. 39, no. 4, pp. 802-835, 1996.

[20] H. Enns, E. Murray, and S. Huff, "Shared understanding between IS and business executives: impacts on IS effectiveness and business performance," in Proc. IS Admin. Sci. Assoc. Canada, St. John's, Newfoundland, 1997, pp. 12-23.

[21] M. Entrialgo, "The impact of the alignment of strategy and managerial characteristics on Spanish SMEs," J. Small Bus. Manage., vol. 40, no. 3, pp. 260-270, 2002.

[22] C. Fornell and D. Larcker, "Evaluating structural equation models with unobservable variables and measurement error," J. Market. Res., vol. 18, no. 1, pp. 39-50, 1981.

[23] J. Galbraith, Organizational Design. Reading, MA: Addison-Wesley, 1977.

[24] D. Gefen, E. Karahanna, and D. Straub, "Inexperience and experience with online stores: The importance of TAM and trust," IEEE Trans. Eng. Manage., vol. 50, no. 3, pp. 307-321, Aug. 2003.

[25] C. Gresov, "Exploring fit and misfit with multiple contingencies," Admin. Sci. Quart., vol. 34, no. 3, pp. 431-453, 1989.

[26] Y. P. Gupta, J. Karimi, and T. M. Somers, "Alignment of a firm's competitive strategy and information technology management sophistication: The missing link," IEEE Trans. Eng. Manage., vol. 44, no. 4, pp. 399-413, 1997.

[27] A. J. Hale and P. B. Cragg, "Measuring strategic alignment in small firms," in Proceedings of the Information Systems Conference of New Zealand, Palmerston North, NZ, 1996, pp. 128-135.

[28] J. Hulland, "Use of partial least squares (PLS) in strategic management research: A review of four recent studies," Strategic Manage. J., vol. 20, no. 2, pp. 195-204, Nov. 1999.

[29] H. Hussin, M. King, and P. Cragg, "IT alignment in small firms," Eur. J. Inf. Syst., vol. 11, no. 2, pp. 108-127, 2002.

[30] Z. Irani, "Information systems evaluation: Navigating through the problem domain," Inf. Manage., vol. 40, pp. 11-24, 2002.

[31] S. L. Jarvenpaa and B. Ives, "Organizing for global competition: The fit of information technology," Decision Sci., vol. 24, no. 3, pp. 547-580, 1993.

[32] H. R. Johnston and S. R. Carrico, "Developing capabilities to use information strategically," MIS Quart., vol. 12, no. 1, pp. 37-50, 1988.

[33] J. Karimi, Y. P. Gupta, and T. M. Somers, "Impact of competitive strategy and information technology maturity on firms' response to globalization," J. MIS, vol. 12, no. 4, pp. 55-88, Spring 1996.

[34] G. S. Kearns and A. L. Lederer, "A resource-based view of strategic IT alignment: How knowledge sharing creates competitive advantage," Decision Sci., vol. 24, no. 1, pp. 1-29, 2003.

[35] W. R. King, "Strategic planning for management information systems," MIS Quart., vol. 2, pp. 27-37, 1978.

[36] W. R. King and T. S. H. Teo, "Assessing the impact of proactive versus reactive modes of strategic information systems planning," Omega, vol. 28, pp. 667-679, 2000.

[37] A. L. Lederer and A. L. Mendelow, "Information resource planning: Overcoming difficulties in identifying top management's objectives," MIS Quart., vol. 11, no. 3, pp. 389-400, 1987.

[38] — "Convincing top management of the strategic potential of information systems," MIS Quart., vol. 12, no. 4, pp. 525-535, 1988.

[39] C. Lee and V. Grover, "Exploring mediation between environmental and structural attributes: The penetration of communication technologies in manufacturing organizations," J. Manage. Inf. Syst., vol. 16, no. 3, pp. 189-224, 2000.

[40] M. Levy, P. Powell, and P. Yetton, "SMEs: Aligning IS and the strategic context," J. Inf. Technol., vol. 16, pp. 133-144, 2001.

[41] M. Li and R. Ye, "Information technology and firm performance: Linking with environmental, strategic and managerial contexts," Inf. Manage., vol. 35, pp. 43-51, 1999.

[42] J. N. Luftman and T. Brier, "Achieving and sustaining business-IT alignment," Calif. Manage. Rev., vol. 42, no. 1, pp. 109-122, 1999. 
[43] J. N. Luftman, R. Papp, and T. Brier, "Enablers and inhibitors of business-IT alignment," Commun. AIS, vol. 1, no. 11, pp. 1-32, 1999.

[44] L. L. Martins and A. Kambil, "Looking back and looking ahead: Effects of prior success on managers' interpretations of new information technologies," Acad. Manage. J., vol. 42, no. 6, pp. 652-661, 1999.

[45] S. W. McDaniel and J. W. Kolari, "Marketing strategy implications of the Miles and Snow strategic typology," J. Marketing, vol. 51, no. 4, pp. 19-30, 1987.

[46] R. E. Miles and C. C. Snow, Organizational Strategy, Structure, and Process. New York: McGraw-Hill, 1978.

[47] N. Nohria and R. Gulati, "What is the optimum amount of organizational slack? A study of the relationship between slack and innovation in multinational firms," in Acad. Manage. Best Papers Proc., 1995, pp. 32-36.

[48] K. E. Papke-Shields and M. Malhotra, "Assessing the impact of the manufacturing executive's role on business performance through strategic alignment," J. Oper. Manage., vol. 19, no. 1, pp. 5-22, 2001.

[49] J. L. Perry and H. G. Rainey, "The public-private distinction in organization theory: A critique and research strategy," Acad. Manage. Rev., vol. 13, no. 2, pp. 182-201, 1988.

[50] N. Rackoff, C. Wiseman, and W. A. Ullrich, "Information systems for competitive advantage: Implementation of a planning process," MIS Quart., vol. 12, pp. 285-294, 1988.

[51] B. Raghunathan and T. S. Raghunathan, "Information systems planning and effectiveness: An empirical analysis," OMEGA Int. J. Manage. Sci., vol. 19 , no. 2/3, pp. 125-135, 1991.

[52] H. G. Rainey, Understanding and Managing Public Organizations. San Francisco, CA: Jossey-Bass, 1997.

[53] T. Ravichandran and A. Rai, "Structural analysis of the impact of knowledge creation and knowledge embedding on software process capability," IEEE Trans. Eng. Manage., vol. 50, no. 3, pp. 370-284, Aug. 2003.

[54] B. H. Reich and I. Benbasat, "Measuring the linkage between business and information technology objectives," MIS Quart., vol. 20, no. 1, pp. $55-81,1996$.

[55] _ _ "Factors that influence the social dimension of alignment between business and information technology objectives," MIS Quart., vol. 24, no. 1, pp. 81-113, 2000.

[56] R. Sabherwal and Y. E. Chan, "Alignment between business and IS strategies: A study of prospectors, analyzers, and defenders," Inf. Syst. Res., vol. 12, no. 1, pp. 11-33, 2001.

[57] R. Sabherwal and P. Kirs, "The alignment between organizational critical success factors and information technology capability in academic institutions," Decision Sci., vol. 25, no. 2, pp. 301-330, Mar./Apr. 1994.

[58] v. Sambamurthy and R. W. Zmud, "Arrangements for information technology governance: A theory of multiple contingencies," MIS Quart., vol. 23, no. 2, pp. 261-290, 1999.

[59] W. R. Scott, Institutions and Organizations. Thousand Oaks, CA: Sage, 1995.

[60] N. Shin, "The impact of information technology on financial performance: The importance of strategic choice," Eur. J. Inf. Syst., vol. 10, no. 4, pp. 227-236, 2001.

[61] P. P. Tallon, K. L. Kraemer, and V. Gurbaxani, "Executives' perceptions of the business value of information technology: A process-oriented approach," J. Manage. Inf. Syst., vol. 16, no. 4, pp. 145-173, 2000.

[62] F. B. Tan, "The responsiveness of information technology to business strategy formulation: An empirical study," J. Inf. Technol., vol. 10, no. 3, pp. $171-178,1995$

[63] B. Townley, "The institutional logic of performance appraisal," Org. Studies, vol. 18, no. 2, pp. 261-285, 1997.

[64] A. H. Van de Ven and R. Drazin, "The concept of fit in contingency theory," in Res. Org. Behav., L. L. Cummings and B. M. Staw, Eds. Greenwhich, CT: JAI Press, 1985, vol. 7, pp. 333-385.

[65] M. Van Gelderen, M. Frese, and R. Thurik, "Strategies, uncertainty and performance of small business startups," Small Bus. Econ., vol. 15, no. 3 , pp. $165-181,2000$.

[66] N. Venkatraman, "The concept of fit in strategy research: Toward verbal and statistical correspondence," Acad. Manage. Rev., vol. 14, no. 3, pp. 423-444, 1989

[67] M. R. Vitale, B. Ives, and C. M. Beath, "Linking information technology and corporate strategy: An organizational view," in Proc. 7th Int. Conf. Inf. Syst., San Diego, CA, 1986, pp. 256-276.

[68] E. T. G. Wang and J. C. F. Tai, "Factors affecting information systems planning effectiveness: Organizational contexts and planning systems dimensions," Inf. Manage., vol. 40, pp. 287-303, 2003.
[69] C. E. Werts, R. L. Linn, and K. G. Joreskog, "Intraclass reliability estimates: Testing structural assumptions," Educational and Psychological Measurement, vol. 34, pp. 25-33, 1974.

[70] H. Wold, "Soft modeling: The basic design and some extensions," in Systems Under Indirect Observation: Causality, Structure, Prediction, K. G. Joreskog and H. Wold, Eds. New York: North-Holland, 1982, pp. $1-47$.

[71] S. A. Zahra and J. A. Pearce II, "Research evidence on the Miles-Snow typology," J. Manage., vol. 16, no. 4, pp. 751-768, 1990.

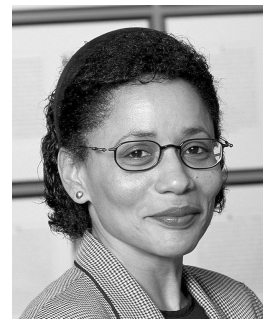

Yolande E. Chan received the S.M. and S.B. degrees in electrical engineering and computer science from the Massachusetts Institute of Technology, Cambridge, the M.Phil. degree in management studies from Oxford University, Oxford, U.K., and the Ph.D. degree from the University of Western Ontario, London, ON, Canada.

She is a Professor and E. Marie Shantz Research Fellow in MIS at the School of Business, Queen's University, Kingston, ON, Canada. She is a Rhodes Scholar. Prior to joining Queen's University, she worked with Andersen Consulting (now Accenture), Toronto, ON, Canada, as a Senior Information Systems Consultant. She conducts research on strategic alignment, knowledge management, information privacy, and information systems performance. She has published her findings in journals such as Information Systems Research, MIS Quarterly Executive, Journal of Management Information Systems, Journal of the Association for Information Systems, Journal of Strategic Information Systems, Information \& Management, Communications of the AIS and The Academy of Management Executive. She serves on the Editorial Boards for several leading journals including MIS Quarterly, MIS Quarterly Executive and the Journal of the Association for Information Systems (JAIS).

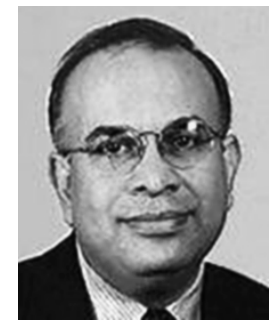

Rajiv Sabherwal received the Ph.D. in business administration (with information systems concentration) from the University of Pittsburgh, Pittsburgh, PA, in 1989, and a Post Graduate Diploma in Management from Indian Institute of Management, Calcutta.

He is a Curators' Professor for the University of Missouri System, the Emery C. Turner Professor of Information Systems at the University of Missouri, St. Louis, and Director of the Ph.D. Program in Business Administration (with information systems emphasis). He has coauthored a textbook on knowledge management. He has previously taught at Florida State University and Florida International University. He worked as a systems analyst in India. He is a Senior Editor of MIS Quarterly, and serves on the Editorial Boards for Information Systems Research and Journal of the Association for Information Systems (JAIS). His research focuses on knowledge management, information systems strategy, and social aspects of systems development. It has been published in journals such as Information Systems Research, MIS Quarterly, Organization Science, Decision Science, IEEE TRANSACTIONS ON ENGINEERING MANAGEMENT, California Management Review, and Communications of the ACM.

$\mathrm{He}$ is the Departmental Editor (information technology) for IEEE TRANSACTIONS ON ENGINEERING MANAGEMENT.

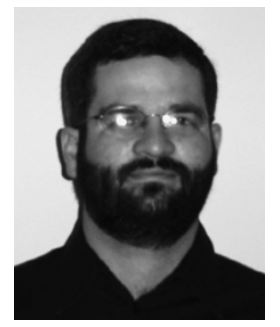

Jason Bennett Thatcher received the Ph.D. degree in management information systems from Florida State University, Tallahassee.

$\mathrm{He}$ is an Assistant Professor in the Department of Management, College of Business and Behavioral Science at Clemson University, Clemson, SC. His work has appeared in MIS Quarterly, Journal of Management Information Systems, and the Journal of Organizational Computing and E-Commerce. His current research interests include individual differences and behavior toward information technology, strategic management of information technology, and the recruitment, motivation, and retention of IT workers. 